\title{
Prospects of genetic testing for steroid-resistant nephrotic syndrome in Nigerian children: a narrative review of challenges and opportunities
}

This article was published in the following Dove Medical Press journal: International Journal of Nephrology and Renovascular Disease

\section{Emmanuel Ademola \\ Anigilaje' \\ Ayodotun Olutola ${ }^{2}$}

'Nephrology Unit, Department of Paediatrics, Faculty of Clinical Sciences, College of Health Sciences, University of Abuja, Abuja, Nigeria; ${ }^{2}$ Center for Clinical Care and Clinical Research, Abuja, Nigeria

Correspondence: Emmanuel Ademola Anigilaje

Nephrology Unit, Department of

Paediatrics, Faculty of Clinical Sciences, College of Health Sciences, University of Abuja, 23 Airport-Giri Road, PMB II7, Abuja, Nigeria

Tel +2348033833839

Email demolaanigilaje2@gmail.com

\begin{abstract}
The prevalence of childhood steroid-resistant nephrotic syndrome (SRNS) ranges from $35 \%$ to $92 \%$. This steroid resistance among Nigerian children also reflects underlying renal histopathology, revealing a rare minimal-change disease and a varying burden of membranoproliferative glomerulonephritis and focal segmental glomerulosclerosis (FSGS). FSGS tends to progress to end-stage kidney disease, which requires dialysis and/or renal transplantation. While knowledge of the molecular basis of NS is evolving, recent data support the role of mutant genes that otherwise maintain the structural and functional composition of the glomerular filtration barrier to account for many monogenic forms of FSGS. With the advent of next-generation sequencing, >39 genes are currently associated with SRNS, and the number is likely to increase in the near future. Monogenic FSGS is primarily resistant to steroids, and this foreknowledge obviates the need for steroids, other immunosuppressive therapy, and renal biopsy. Therefore, a multidisciplinary collaboration among cell biologists, molecular physiologists, geneticists, and clinicians holds prospects of fine-tuning the management of SRNS caused by known mutant genes. This article describes the genetics of NS/SRNS in childhood and also gives a narrative review of the challenges and opportunities for molecular testing among children with SRNS in Nigeria. For these children to benefit from genetic diagnosis, Nigeria must aspire to have and develop the manpower and infrastructure required for medical genetics and genomic medicine, leveraging on her existing experiences in genomic medicine. Concerted efforts can be put in place to increase the number of enrollees in Nigeria's National Health Insurance Scheme (NHIS). The scope of the NHIS can be expanded to cater for the expensive bill of genetic testing within or outside the structure of the National Renal Care Policy proposed by Nigerian nephrologists.
\end{abstract} Keywords: child, humans, nephrotic syndrome, genetic testing

\section{Introduction}

Nephrotic syndrome (NS) is the commonest chronic glomerular disease in children characterized by heavy proteinuria. ${ }^{1-3}$ This is accompanied by hypoalbuminemia, hyperlipidemia, and generalized edema..$^{1-3}$ Clinical features can include acute lifethreatening conditions, such as hypovolemia, acute kidney injury, hypercoagulation, thromboembolism, and infection. ${ }^{4,5}$ When NS does not respond to treatment, it also progresses to chronic kidney disease (CKD) and end-stage KD (ESKD). ${ }^{6}$

The annual incidence of NS in the US and Europe ${ }^{7}$ is estimated at seven in 100,000; however, the overall incidence of NS is difficult to estimate in Africa. ${ }^{8}$ The limited data in Africa is a result of a lack of pediatric nephrologists, poor access to diagnostic 
tools, such as electron and immunofluorescence microscopes, weak capacity for renal biopsies, and inadequate reporting of renal diseases. ${ }^{8}$ Cumulatively, these challenges make NS undiagnosed, underdiagnosed, and underreported in Africa.

In a broad classification, childhood NS can be secondary, congenital, infantile, and idiopathic. ${ }^{3}$ Secondary NS refers to etiology that is not intrinsic to the kidney. ${ }^{3,9}$ The causes of secondary NS include 1) autoimmune and vasculitic diseases, such as Henoch-Schönlein purpura, systemic lupus erythematosus, and antineutrophil cytoplasmic antibody-associated vasculitis, 2) infectious diseases, such as congenital syphilis, malaria, HIV, and hepatitis B and C, 3) malignancy, 4) environmental and drug exposure, such as heroin and mercury, and 5) systemic diseases, such as diabetes mellitus, among many other causes. ${ }^{3,9}$ While congenital NS (CNS) manifests in the first 3 months of life, infantile NS is seen in children from 3 months to 12 months of life. ${ }^{3,9}$ When NS is not congenital, infantile, or secondary, it is said to be idiopathic NS (INS). ${ }^{3}$

Variants of INS include membranous nephropathy, membranoproliferative glomerulonephritis (MPGN), C3 glomerulonephritis, IgA nephropathy, and diffuse mesangial proliferation. However, the histological classifications of INS are either minimal change disease (MCD) or focal segmental glomerulosclerosis (FSGS). ${ }^{3,10}$

Under light microscopy, the glomerulus in MCD appears normal; however, electron microscopy reveals effacement of podocyte foot processes. Light microscopy findings in FSGS include segmental destruction of glomerular capillaries and fusion between Bowman's capsule and the sclerosed segments. Electron-microscopy findings are however similar to $\mathrm{MCD} .{ }^{9,10}$

Clinically, INS can be classified as a steroid-sensitive NS or steroid-resistant NS (SRNS), as the response to steroids correlates with histological subtype and prognosis. ${ }^{11,12}$ Primary SRNS is lack of remission in proteinuria despite 4 weeks' treatment with prednisolone at a daily dose of $60 \mathrm{mg}$ / $\mathrm{m}^{2}$ followed by $40 \mathrm{mg} / \mathrm{m}^{2}$ on alternate days for 4 weeks. ${ }^{9,12}$ Secondary SRNS refers to the development of steroid resistance in a child with a previous steroid-sensitive disease. ${ }^{9,12}$ Remission in proteinuria is commonly described as 3 consecutive days of zero or trace proteinuria during steroid treatment for NS. ${ }^{9,12}$

In the Western hemisphere, MCD is found on renal biopsy in the vast majority ( $80 \%$ ) of preadolescent children with INS. ${ }^{11,12}$ Response to steroids has been reported in $90 \%$ of MCD cases and only $30 \%$ of FSGS cases. ${ }^{11-14}$ Also, children with FSGS tend to progress to ESKD requiring a renal transplant, with a risk of recurrence of $30 \%-50 \%$ in the first transplanted kidney and a higher risk of recurrence in subsequent renal grafts. ${ }^{15}$

In Africa, MCD NS with good treatment outcome to steroids also predominates in temperate regions. ${ }^{16-19}$ In tropical Africa and from the 1960s to 1980s, steroid-resistant non-MCD, including quartan malaria nephropathy, was the dominant renal histopathology type. ${ }^{20-23}$ However, in the years after 1989, proliferative glomerulonephritis, MCD, and FSGS took predominance..$^{20,24-26}$

In Nigeria, geographical variations put steroid resistance at $35 \%-92 \%$ for children with $\mathrm{NS}^{27-37}$ and $17.2 \%-54.8 \%$ for children with INS. ${ }^{32,35,37}$ This steroid resistance parallels the underlying renal histopathology, which reveals a rarity of MCD, but a varying burden of MPGN, focal mesangial proliferative lesion, and FSGS. ${ }^{27,32,34,37,38}$ It would also appear that there is a transition from quartan malaria nephropathy through MPGN to FSGS in Nigeria,,$^{23,30,38-40}$ a finding that is also consistent with an emerging burden of FSGS among children in Europe, the US, and Asia. ${ }^{41-45}$

While FSGS suggests steroid unresponsiveness, histopathological diagnosis of FSGS is also fraught with the challenge of underdiagnosis from single renal biopsies, because of its focal nature and the small cores of biopsies. , $^{7,46-48}$ In addition, since FSGS has the propensity for deep juxtamedullary glomeruli, FSGS lesions may be missed readily when only cortical glomeruli are biopsied..$^{7,9,46-48}$ Larger samples of glomeruli are thus necessary for the histological diagnosis of FSGS. ${ }^{49,50}$ Differential staining patterns for synaptopodin ${ }^{51}$ and dystroglycan ${ }^{52}$ may also be useful in distinguishing MCD by its response to steroids. ${ }^{47}$

Unfortunately, large-scale efforts at studying steroid responsiveness in children with NS have been only among Caucasians. These studies include PodoNet (European descent), ${ }^{53}$ NephroS (European descent), ${ }^{54}$ NEPTUNE $^{55}$ (North America), CHILDNEPH (Canada), ${ }^{56}$ and INSIGHT ${ }^{57}$ (Canada). It remains arguable that the generalizability of the findings of these studies to African children will be fraught with limitations inherent in the ethnic differences.

The proposed Human Heredity and Health (H3) Africa Kidney Disease Research Network (H3A-KDRN) will provide information on a cohort of children with NS from Ghana, Nigeria, Tanzania, South Africa, and Cameroon. ${ }^{58}$ The H3A-KDRN will determine if clinical, infectious, and genetic factors account for variability in initial steroid response, steroid resistance, frequent relapse/steroid dependence, and CKD-progression course (over 4 years) in childhood NS. ${ }^{58}$ Africa and indeed Nigeria provide a great opportunity to 
study diversities in human genetics by virtue of their widely varied population, climate, diet, and exposure to infectious diseases. ${ }^{59}$

While the H3A-KDRN findings are being awaited, this paper seeks to review the prospects of having the capacity for genetic testing as part of a standard of care in the management of NS/SRNS in Nigerian children. Based on the existing resource-constrained health-care system in Nigeria, this article gives a narrative review of the challenges against the prospects of genetic testing, and also highlights the opportunities available for genetic testing for the management of SRNS among Nigerian children. The article will be valuable to all clinicians caring for children with NS/SRNS in developing countries who may be having similar challenges and opportunities for genomic medicine as exist in Nigeria.

\section{Focal segmental glomerulosclerosis and steroid-resistant nephrotic syndrome}

FSGS is the most common cause of SRNS and a significant cause of ESRD. ${ }^{3,47,48,60}$ FSGS ensues from podocyte injury by many pathogenic mechanisms that result in loss of selectivity of the glomerular filtration barrier (GFB). ${ }^{47,48}$ These underlying pathogenic mechanisms have also been used in its classification. ${ }^{47,48}$

FSGS is classified into primary (idiopathic) and secondary forms. ${ }^{48,61}$ The secondary forms include 1) virusassociated forms (HIV1, cytomegalovirus, parvovirus B19, and Epstein-Barr virus, and other parasites, including Plasmodium, Schistosoma mansoni and filariasis), ${ }^{62,63} 2$ ) drug-induced forms (IFN $\alpha,-\beta$, or $-\gamma$ therapy, bisphosphonates, lithium, heroin, sirolimus, doxorubicin, and daunomycin), ${ }^{64-68} 3$ ) forms mediated by adaptive structural-functional responses (ie, conditions associated with increased total kidney glomerular filtration rate like congenital cyanotic heart disease, sickle-cell anemia, obesity, androgen abuse, sleep apnea, and high-protein diet, and conditions associated with reduced renal mass, including prematurity and/or small for gestation age, renal anomalies, reflux nephropathy, and acute kidney injury), ${ }^{69-74}$ and 4) familial/genetic forms. ${ }^{48,61}$

The primary/idiopathic form is a diagnosis of exclusion after ruling out secondary forms of FSGS. The pathogenesis of primary FSGS probably involves a circulating factor. ${ }^{75-79}$ While it is unclear what may be the circulating factor, possible candidates include CLCF1, ApoA1 ${ }^{\text {b }}$ (an isoform of ApoA1), anti-CD40 antibody, and suPAR. ${ }^{75-79}$ Widespread foot-process effacement on electron microscopy characterizes podocyte injury in primary FSGS, and it is commonly associated with nephrotic-range proteinuria (sometimes massive), reduced plasma albumin levels, and hyperlipidemia. ${ }^{47,80}$ Primary FSGS also tends to respond to immunosuppressive treatment. ${ }^{80}$ Electron-microscopy features of podocytopathy in adaptive FSGS are segmental effacement of foot processes, and present clinically with normal serum albumin. ${ }^{47,80,81}$ The management of secondary FSGS requires the elimination of the causative agent, reducing hemodynamic pressure on glomeruli (eg, weight loss), and instituting antiproteinuric strategies. ${ }^{80}$

Since the discovery of mutations in nephrin (NPHS1) by Kestilä et al in 1998 as the cause of podocyte dysfunction in $\mathrm{CNS},{ }^{81}$ over 36 other genes have been described for genetic FSGS. ${ }^{83,84}$ The term "genetic FSGS" has been coined based on the discovery of genes that if mutated can cause monogenic forms of FSGS in humans. ${ }^{84}$ While details of genetic FSGS will be discussed subsequently in the next section, it is important to introduce Apol1, which is emerging as a peculiar form of primary FSGS in populations of African descent. ${ }^{47,85,86}$ Apol1 FSGS progresses more rapidly to ESRD, but also has the prospect of having therapy targeted at Apol1 variant-driven molecular pathways..$^{85,86}$

\section{Clinical implications of genetic forms of nephrotic syndrome}

Researchers over the years have enhanced efforts at finding ways of predicting steroid responsiveness in individuals with NS. ${ }^{87-89}$ This knowledge will enable clinicians to spare children that do not respond to steroids, unwarranted side effects of steroids, and at the same time provide a timely alternative management plan to include the use of second-line immunosuppressive agents. ${ }^{87-89}$ It will also obviate the need for renal biopsy and enable clinicians to prioritize early renal transplantation for children that do not respond to immunosuppressive therapies. ${ }^{87-89}$ There is a low risk of disease reoccurrence posttransplant when a genetic aetiology has been confirmed..$^{90}$ On the other hand, the risk of post-transplant disease is high in idiopathic NS as the circulating factors settle and damage the new allograft. ${ }^{90}$ While living related transplant donors may be acceptable in recessive mutations, it excludes these donors in cases of dominant mutations.$^{89}$ Carriers of WT1 mutations are monitored closely for Wilms tumor and gonadoblastoma. ${ }^{89}$ Familial genetic counseling advocates for prenatal diagnosis in autosomal-dominant patients of childbearing age ${ }^{89}$ Interestingly, concerted research efforts have so far identified some noninvasive biomarkers of SRNS. These biomarkers include some elevated urinary factors (suPAR, urinary CD80) and some elevated serum factors (DBP, prealbumin, NGAL, fetuin A, and $\alpha_{2}$ macroglobulin). ${ }^{88,89,91-95}$ 
However, limitations in the clinical application of SRNS biomarkers include unavailability of these biomarkers in most laboratories, requirement for longitudinal studies to establish its validity as a noninvasive predictor of steroid unresponsiveness, ${ }^{88,89}$ and lack of specificity of some biomarkers (urinary fetuin A and NGAL) requiring that the SRNS to be of longstanding duration to cause proximal tubular megalin dysfunction (megalin endocytosis reabsorbs these filtered proteins back into the bloodstream). ${ }^{96,97}$ In addition, studies that identified these biomarkers were not powered sufficiently in their sample sizes and were not multicenter studies ${ }^{88}$ This limits the generalizability of the clinical usefulness of these biomarkers. ${ }^{88,91}$

\section{Genetics of nephrotic syndrome}

From the discovery in 1998 of mutations in nephrin (NPHS1) among a subset of CNS, ${ }^{82}$ many other mutations affecting genes that affect the integrity of the GFB have been found to account for many secondary genetic forms of FSGS. ${ }^{83,84}$ With newer sequencing techniques, over 36 genes are currently associated with SRNS, ${ }^{84,98-104}$ with great prospects for new discoveries.

The GFB is made up of three layers that functionally prevent plasma proteins from passing into the urine. These layers are the endothelium, glomerular basement membrane, and visceral epithelial cells, also known as podocytes. ${ }^{84,105}$ Podocytes are highly differentiated neuron-like cells made up of a cell body, with primary, secondary, and tertiary cellular processes that wrap around the capillaries, leaving slits between them ${ }^{83,84}$ (Figure 1). ${ }^{84}$ The integrity of the GFB is lost in NS, and the identification of single-gene causes of SRNS has revealed proteins, each of which is an indispensable component of glomerular function, with consequent proteinuria and FSGS. ${ }^{105}$ However, studies of familial NS/FSGS found that virtually all the gene mutations causing NS/FSGS were localized to podocytes in hereditary SRNS. ${ }^{106-112}$ This

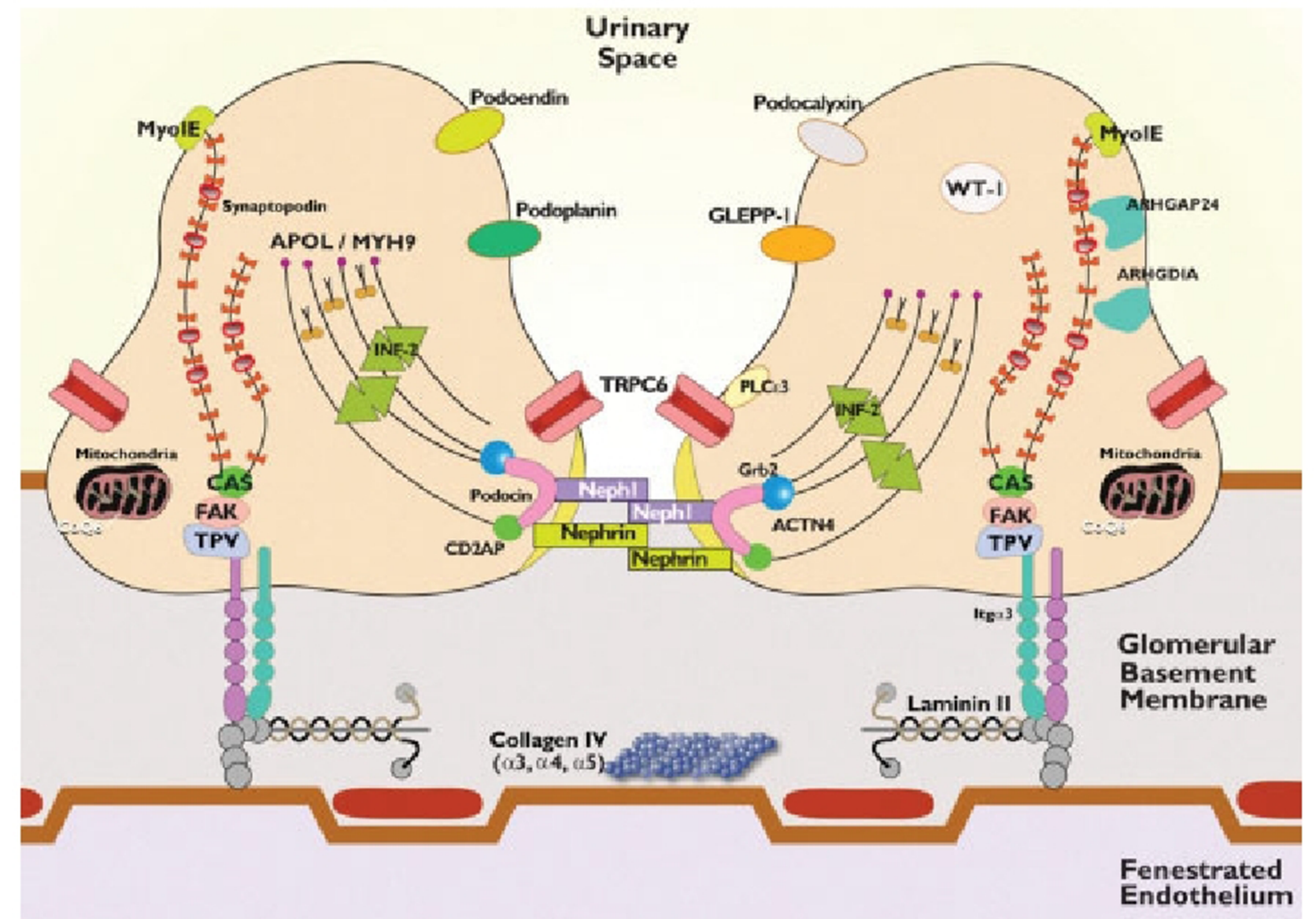

Figure I Proteins involved in single-gene causes and pathogenic pathways of SRNS.

Note: Rheault MN, Gbadegesin RA. The Genetics of Nephrotic Syndrome. J Ped Gen. 2016;5(I): No. I/2016. Doi: http://dx.doi.org//0.1055/s-0035-I557I09.84 
gave rise to the concept of podocytopathy being the underlying pathology in most cases of NS, especially FSGS. ${ }^{113}$ The known podocyte genes do not explain $>20 \%-30 \%$ of hereditary NS; however, they do explain $57 \%-100 \%$ of familial and infant-onset NS compared with $10 \%-20 \%$ of sporadic cases. ${ }^{83}$

Mutations affect both functional and structural proteins that are involved in several vital pathways including those involved in slit diaphragm structure and function, podocyte actin cytoskeletal organization, co-enzyme $\mathrm{Q}$ biosynthesis, lysosomal pathways, and adhesion to the GBM. (Figure 1). ${ }^{84}$ Genes responsible for SRNS/genetic FSGS are also inherited in autosomal-recessive and -dominant fashion and are either isolated disorders or a component of a multisystem genetic disorder (see Table 1 for the list of autosomal and determinant genes). ${ }^{84}$

The main mutations causing autosomal-recessive NS are in nephrin (NPHS1), podocin (NPHS2), and PLCE1, while the main autosomal-dominant NS mutations include those in INF2, TRPC6, WT1, and ACTN4. ${ }^{14}$ Genetic risk factors of MYH9 and APOL1 (associated with pathological features of FSGS in African-Americans) are increasingly being found to be similar to those of FSGS and complex inheritance patterns of FSGS. ${ }^{11,115}$

In recessive mutations, presentation occurs in childhood, history of NS is often negative, parents of index patients are mostly healthy heterozygous carriers, and there is no ancestral history of the disease. ${ }^{104}$ However, in dominant disease, it occurs in adulthood, one of the parents of the index patient is most probably affected, and the disease may have been passed on from generation to generation (with the exception of spontaneous mutations or incomplete penetration). ${ }^{104}$ Dominant mutations also have important clinical implications, as disease-causing mutations in the related donor have to be excluded before acceptance for planned living related donor kidney transplantation, as SRNS just may not yet have manifested. ${ }^{84}$

\section{Approach to genetic testing in steroid-resistant nephrotic syndrome}

Gbadegesin et al ${ }^{14}$ suggested pertinent questions that warrant answering before a genetic test is requested for. Will this result assist in establishing the diagnosis? Will the test result modify the patient's treatment or improve prognosis? Will the test result provide information to predict risk among other family members? Within the context of monogenic SRNS, the answers to these questions are "Yes".

To answer the first question, about 53 monogenic genes have already been identified as being responsible for SRNS/ FSGS ${ }^{86,98-104}$ In addition, certain phenotypic characteristics like age of onset of disease also exist that can suggest the type of mutations in individuals with SRNS. ${ }^{98,116}$ Early-childhood onset of disease is associated with mutations in the recessive genes NPHS1, LAMB2, or PLCE1, whereas others, such as NPHS2, cause onset in later childhood. ${ }^{98,116}$ With the exception of $W T 1$, mutations in dominant SRNS genes (ACTN4, TRPC6, INF2, ANLN, and ARHGAP24) cause adult-onset SRNS. ${ }^{98}$ In "multiple allelism" (ie, within the same gene, specific mutations may determine a range for age of onset of SRNS that is dependent on the specific mutation), R138Q NPHS2 mutations cause onset in early childhood, ${ }^{117,118}$ whereas the mutation R229Q in compound heterozygosity with specific second mutations causes adult-onset SRNS. ${ }^{119}$

Even when genetic testing can be expensive, the result of genetic testing in SRNS alters the management of the patient or better informs a discussion of likely outcomes and prognosis. First, immunosuppressive therapy can be avoided in some patients who will not benefit from it, likewise renal biopsy. Treatment with coenzyme Q10 may be indicated for children with gene mutations of coenzyme Q10 biosynthesis (COQ2, COQ6, ADCK4, or PDSS2). Likewise, steroids or cyclosporine A may benefit patients with recessive mutations in PLCE $1,{ }^{104,120}$ and cyclosporine A can also induce steroid responsiveness in some individuals with NPHS1 and NPHS2 mutations. ${ }^{121}$ Second, while the recurrence rate of FSGS in familial/idiopathic SRNS is reported to be $\sim 30 \%$ (as high as $75 \%$ in those who progress to ESRD in 3 years). ${ }^{122,123}$ Contrariwise, an estimated $0-2.5 \%$ recur after renal transplantation, making recurrence rare in genetic forms of FSGS. This encourages an earlier plan for renal transplantation, with the assurance that recurrence of FSGS in the posttransplanted kidney is rare. ${ }^{124-127}$ Third, selection of donors for patients with genetic FSGS among family members will require careful screening considering the risks of the donor. In fact, studies have reported cases of FSGS in the remaining kidney among donors after organ donation. ${ }^{128}$ Depending on the Mendelian mode of inheritance as either a recessive or dominant gene, the index patient with SRNS can be a predictor of risk in other family members as enumerated previously. ${ }^{104}$ 
Table I Steroid resistant nephrotic syndrome

\begin{tabular}{|c|c|c|c|}
\hline Gene & Protein & Mode of Inheritance & $\begin{array}{l}\text { Syndrome or extrarenal } \\
\text { manifestations }\end{array}$ \\
\hline \multicolumn{4}{|c|}{ Slit diaphragm associated } \\
\hline CD2AP & CD2-associated protein & \begin{tabular}{|l|} 
Autosomal recessive/ \\
autosomal dominant
\end{tabular} & \\
\hline NPHSI & Nephrin & Autosomal recessive & \\
\hline NPHS2 & NPHS2 & Autosomal recessive & \\
\hline PLCEI & Phospholipase C, $\varepsilon$ I & Autosomal recessive & \\
\hline TRPC6 & $\begin{array}{l}\text { Transient receptor potential cation } \\
\text { channel, subfamily C, member } 6\end{array}$ & Autosomal dominant & \\
\hline \multicolumn{4}{|c|}{ Actin cytoskeleton } \\
\hline ACTN4 & $\alpha$-Actinin 4 & Autosomal dominant & \\
\hline ANLN & Anillin & Autosomal dominant & \\
\hline ARHGAP24 & Rho GTPase activating protein 24 & Autosomal dominant & \\
\hline ARHGDIA & RhoGDP dissociation inhibitor $\alpha$ & Autosomal recessive & \\
\hline INF2 & Inverted formin 2 & Autosomal dominant & Charcot-Marie-Tooth \\
\hline YOIE & Nonmuscle myosin le & Autosomal recessive & \\
\hline \multicolumn{4}{|c|}{ Mitochondrial proteins } \\
\hline$A D C K 4$ & aarF domain containing kinase 4 & Autosomal recessive & \\
\hline COQ2 & $\begin{array}{l}\text { Coenzyme Q2 4-hydroxybenzoate } \\
\text { polyprenyl transferase }\end{array}$ & Autosomal recessive & Seizures, encephalopathy \\
\hline COQ6 & Coenzyme Q6 monooxygenase & Autosomal recessive & Sensorineural deafness \\
\hline MTTLI & tRNA-LEU & Unknown & $\begin{array}{l}\text { Mental retardation, diabetes } \\
\text { mellitus, MELAS syndrome }\end{array}$ \\
\hline PDSS2 & Prenyl diphosphate synthase subunit 2 & Autosomal recessive & $\begin{array}{l}\text { Encephalomyopathy, Leigh } \\
\text { syndrome }\end{array}$ \\
\hline \multicolumn{4}{|c|}{ Adhesion and glomerular basement membrane proteins } \\
\hline COL4A3 & $\alpha 3$ type IV collagen & Autosomal recessive & Sensorineural deafness \\
\hline COL4A4 & $\alpha 4$ type IV collagen & Autosomal recessive & Sensorineural deafness \\
\hline COL4A5 & $\alpha 5$ type IV collagen & X-linked & Sensorineural deafness \\
\hline ITGA3 & Integrin $\alpha 3$ & Autosomal recessive & $\begin{array}{l}\text { Interstitial lung disease, } \\
\text { epidermolysis bullosa }\end{array}$ \\
\hline ITGB4 & Integrin $\beta 4$ & Autosomal recessive & Epidermolysis bullosa \\
\hline LAMB2 & Laminin $\beta 2$ & Autosomal recessive & Pierson syndrome \\
\hline \multicolumn{4}{|c|}{ Nuclear transcription factors } \\
\hline$L M X I B$ & LIM homeobox transcription factor I $\beta$ & Autosomal dominant & Nail-patella syndrome \\
\hline NXF5 & Nuclear RNA export factor 5 & X-linked & Cardiac conduction disorder \\
\hline SMARCLI & SMARCA-like protein & Autosomal recessive & Schimke immuno-osseous dysplasia \\
\hline WTI & Wilms tumor I & Autosomal dominant & Denys-Drash, Frasier syndrome \\
\hline \multicolumn{4}{|l|}{ Others } \\
\hline CFH & Complement factor $\mathrm{H}$ & Autosomal recessive & $\begin{array}{l}\text { Atypical hemolytic uremic } \\
\text { syndrome }\end{array}$ \\
\hline CUBN & Cubilin & Autosomal recessive & Megaloblastic anemia \\
\hline DGKE & Diacylglycerol kinase $\varepsilon$ & Autosomal recessive & $\begin{array}{l}\text { Atypical hemolytic uremic } \\
\text { syndrome }\end{array}$ \\
\hline MEFV & Pyrin & Autosomal recessive & Mediterranean fever \\
\hline NEILI & Nei endonuclease VIII-like I & Autosomal recessive & \\
\hline PMM2 & Phosphomannomutase 2 & Autosomal recessive & Congenital defects of glycosylation \\
\hline PTPRO & GLEPPI & Autosomal recessive & \\
\hline SCARB2 & $\begin{array}{l}\text { Lysosomal integral membrane } \\
\text { protein type } 2\end{array}$ & Autosomal recessive & $\begin{array}{l}\text { Action myoclonus, renal failure } \\
\text { syndrome }\end{array}$ \\
\hline WDR73 & WD repeat domain 73 & Autosomal recessive & Galloway-Mowat syndrome \\
\hline ZMPSTE24 & Zinc metalloproteinase STE24 & Autosomal recessive & Mandibuloacral dysplasia \\
\hline
\end{tabular}

Note: Table adapted from Rheault MN, Gbadegesin RA. The Genetics of Nephrotic Syndrome.J Ped Gen. 2016;5(I): No. 1/20 16. DOI: http://dx.doi.org/l0.1055/s-0035-I557/09. ISSN 21 46-4596. ${ }^{84}$

Abbreviations: $A D$, autosomal-dominant; $A R$, autosomal-recessive; CDG, congenital disorders of glycosylation; CNS, congenital nephrotic syndrome; DMS, diffuse mesangial sclerosis; ESRD, end-stage renal disease; FSGS, focal segmental glomerulosclerosis; GBM, glomerular basement membrane; HDR, hypoparathyroidism, sensorineural deafness, and renal abnormalities; MELAS, mitochondrial encephalomyopathy, lactic acidosis and stroke-like episodes; NA, not available; NS, nephrotic syndrome; SRNS, steroid-resistant NS; SSNS, steroid-sensitive NS; WAGR, Wilms tumor, aniridia, genitourinary anomalies, and mental retardation I. 
However, it is equally important to highlight the limitations of genetic testing for SRNS. Only a small proportion of genetic tests $(<2 \%)$ for NS are likely to identify a clinically relevant mutation. ${ }^{14}$ Considering the costs, genetic testing for SRNS requires proper selection. ${ }^{14}$ Likewise, a negative test does not exclude the diagnosis, as many cases of genetic NS or FSGS are heterogeneous in nature. ${ }^{14}$ Besides, most of the genetic testing has been among non-African children, ${ }^{83,98-104}$ where allelic variations may occur. ${ }^{128}$ The currently known genes associated with SRNS account for only $20 \%-30 \%$ of hereditary and $10 \%-20 \%$ of sporadic cases. ${ }^{128}$ It is suggested that ethnicity plays a role in the differences in disease burden across countries, but differences among response to steroids and other treatment modalities among specific ethnic groups are not well understood. ${ }^{128}$

Hitherto, Lovric et al ${ }^{104}$ have suggested genetic testing for children with SRNS/FSGS $<25$ years of age, as there is a higher probability of detecting a mutant gene for steroid unresponsiveness. However, going by the comprehensive study of Santin et al among patients with NS, family history of NS and early-onset disease were the risk factors associated with mutations. ${ }^{129}$ Although no consensus exists, the current evidence provided by Santin et al and other epidemiological data, an appropriate, simple, costeffective, and informed approach to genetic testing for SRNS-related mutations can be determined on the basis of current evidence in scenarios with 1) family history of SRNS, 2) congenital or infantile onset ( $<1$ year) of SRNS, 3 ) onset of SRNS before 25 years of age, 4 ) lack of response to immunosuppressive drugs, 5) histological findings of idiopathic FSGS or diffuse mesangial sclerosis, 6) syndromic manifestations, 7) impaired renal function or renal failure, and 8) certain ethnic groups. . $^{14,130,131}$

\section{Clinical testing vs research-based testing}

Clinical genetic testing refers to determining the mutations responsible for a monogenic disease. This can only be conducted by a certified clinical genetic testing laboratory that issues results for clinical decision-making (eg, Clinical Laboratory Improvement Amendments certification). ${ }^{104}$ However, research laboratories continue to remain relevant, as they are needed to continue to discover unidentified rare and novel monogenic genes. Even when they have the capacity to identify disease-causing mutations, research laboratories cannot provide results with clinical judgment, except when such results are subjected to Clinical Laboratory Improvement Amendments certification. ${ }^{104}$

\section{Gene panels}

Gene-panel analysis (GPA) is currently the most advantageous approach in terms of cost and efficacy for mutation detections. ${ }^{98,132,133}$ In GPA, known exon primers that identify mutations are utilized. ${ }^{104}$ Panels with gene sequences of disorders are utilized. ${ }^{104}$ Sanger sequencing is used ${ }^{84}$ The advantages of GPA are in its cheapness, fastness, and the fact that positive results can be interpreted easily without extensive bioinformatics. ${ }^{104}$ However, a negative result may not indicate a lack of mutations, as mutations may exist in noncoding regions of the genes or mutations in new genes. ${ }^{104}$

\section{Whole-exome sequencing}

Whole-exome sequencing (WES) involves the use of an advanced technology of "next-generation sequencing" to sequence the whole human exome. ${ }^{103,134}$ This technology will likely decrease the need for GPA and become the preferred approach in the future. ${ }^{14}$ The major advantage of WES is that it has a higher yield, as its results are restricted to candidate genes and it can also detect mutations in novel genes. ${ }^{14}$ The latter further expands the body of knowledge on the genetic basis of NS and therapeutic targets. ${ }^{14}$ Currently, the use of WES is limited to research laboratories, and results require robust bioinformatic support for interpretation. ${ }^{14}$ In addition, WES may inadvertently detect mutations that are irrelevant to the disease under investigation. ${ }^{135}$

\section{Whole-genome sequencing}

Whole-genome sequencing (WGS) sequences the entire genome utilizing parallel DNA-enrichment technology including noncoding and highly variable segments. ${ }^{14,104}$ WGS is the most extensive sequencing technique and is very expensive. ${ }^{104}$ In monogenic disease, mutations outside the exons bear no direct role in protein synthesis; WGS may thus appear to have no comparative advantage over WES. ${ }^{104}$ However, WGS also identifies promotor and deep intronic mutations relating to protein expression and RNA splicing and is useful in monogenetic disease caused by mutations occurring outside the exons. ${ }^{137}$ For example, in Frasier syndrome where mutations exist in the KTS (Splice insertion) site of the WT1 gene, (not in the exons per se), causing a defective WT1 protein structure..$^{90}$

\section{Genetic counseling in steroid- resistant nephrotic syndrome and/ or genetic FSGS}

Genetic counseling is a communication process that involves explanation of the contribution of genetics to health, trans- 
mission risks of a trait, and modalities to manage the condition or its transmission. Counselors are required to possess the skills to communicate in a neutral, nondirective manner and support the individual and family to cope with decisions made. ${ }^{137,138}$

Genetic counseling includes the services of a genetic counselor, geneticist, and cell biologist or molecular physiologist that work in a clinical research laboratory. ${ }^{137,138}$ While a pediatric nephrologist can serve the role of a genetic counselor, it must be noted that their role is not to advise or recommend, but to provide information and support for the patient/family members to decide.

In the context of SRNS, the first step is to establish the diagnosis of SRNS as defined previously., ${ }^{9,21}$ This is the most crucial step in any genetic consultation. It will include comprehensive history-taking, obtaining a detailed family history that lists the patient's relatives (including abortions, stillbirths, and deceased persons) with their sex, age, and state of health, up to and including third-degree relatives. It involves gathering information on prenatal, pregnancy, and delivery histories. The counselor should know about the latest available genetic information concerning SRNS, and there should be an avenue for communicating the latest information on SRNS. A thorough physical examination of the affected individual should be conducted. All this information will dictate the type of genetic testing that will be requested for the patient. The counseling sessions must include education on the specific genetic mutation, knowledge on the diagnosis of the particular condition, the natural history of the condition, the genetic aspects of the condition, the risk of recurrence and prevention, therapies, and referral. It will include calculating, qualifying, and quantifying the risk of the SRNS in proper context. Knowledge of the known genes for SRNS will guide in counseling about the age of onset and its mode of inheritance.

A satisfactory counseling session must have answered the possible envisaged genetic mutation, the possible etiology or inheritance pattern, the natural history of the genetic mutation, the best mode of therapy available, the mode of inheritance of the disorder, and the risk of developing and/ or transmitting it. The technique of genetic counseling also entails presenting the information clearly in a sympathetic and appropriate manner. Counselors are expected to listen patiently and be receptive to patients' and caregivers' perspectives on issues carefully, being receptive to the fears and aspirations of the family. The environment should be comfortable for the patient, offer confidentiality, and be at a time that allows for detailed uninterrupted discussions.
Communication should be in simple terms and medical terms should be avoided, and if necessary should be well explained. All questions should be honestly and exhaustively addressed.

\section{Steroid-resistant nephrotic syndrome among Nigerian children}

Although a lot of studies have been done on NS in Nigerian children, very few have actually reported on their responsiveness to steroid therapy. Nevertheless, geographical variations put steroid resistance at 35\%-92\% for children with $\mathrm{NS}^{24,27-37}$ and $17.2 \%-54.8 \%$ for children with INS. ${ }^{32,35,37}$ These rates of steroid resistance also parallel the underlying histopathology, which reveals a rarity of $\mathrm{MCD}$, but studies have reported MPGN in northwest Nigeria, ${ }^{27}$ focal mesangial proliferative lesion in north-central Nigeria, ${ }^{34}$ and FSGS in south-south ${ }^{32}$ and southwest Nigeria. ${ }^{37,38}$

In fact, it would appear that there is a transition from quartan malaria glomerulopathy through MPGN to FSGS in southwest Nigeria, ${ }^{23,30,38}$ a finding also consistent with an emerging burden of FSGS among children in Europe, the US, Asia, and South Africa. ${ }^{41-45}$ There is little information on childhood NS in northeast Nigeria, a finding that also signifies a dearth of pediatric nephrologists in that geopolitical region of Nigeria. See Figure 2 for the 6 geopolitical zones in Nigeria.

Although the lack of electron and immunofluorescence microscopes may have contributed to the rarity of MCD and MPGN, respectively, improvements in the National Malaria Control Programme and increased accessibility to vaccines against viral hepatitis B could also account for the decline in secondary NS and the propensity to have nonminimal (ie, FSGS) disease outcome. ${ }^{34,37,38}$ Going by the recent publication of Pelletier et al, ${ }^{141}$ which studied the risks of recurrence of NS following kidney transplantation, it can also be extrapolated that the majority of Nigerian children with FSGS as an underlying histopathological finding may also fare better than those with MCD. Pelletier et al reported that the rate of recurrence in the initial native kidney was $76 \%$ among children with MCD, $40 \%$ among FSGS, and 0 in patients with monogenic NS. ${ }^{141}$

Although few Nigerian studies ${ }^{28-38}$ have mentioned whether steroid resistance is primary or secondary, the unadjusted logistic regression of Pelletier et al revealed that initial steroid responsiveness was associated with higher odds of recurrence in renal grafts. The challenges of Nigerian children with NS and/or SRNS are enormous. ${ }^{34,37}$ There are problems of lack of funding for diagnosis, lack of resources for frequent hospitalizations from complications of SRNS and steroid therapy, 
unaffordability of renal biopsies, high costs of dialysis, unavailability of and lack of funding for procuring second-line immunosuppressive therapies (ie, cyclophosphamide, cyclosporine, mycophenolate) and ancillary medication, and prospects for renal transplantation also being perennially bleak.

Parents and/or caregivers often cannot sustain the management of these children for a long period. ${ }^{34,37}$ Eventually, frustration, despair, and despondency set in, which often make parents seek alternative medicines, including herbal concoctions and other traditional modes of treatment. ${ }^{34,37}$ Nephrotic children are soon lost to follow-up, with a majority progressing to ESKD because of continuous exposure of kidneys to uncontrolled nephrotoxic proteinuria. ${ }^{34,37}$

A good preventive approach to SRNS in Nigeria would be first to document the prevalence and pattern of SRNS. Unfortunately, like other CKDs, this has been hampered by a dearth of epidemiological studies, poor definitions of what SRNS is, and the lack of a renal registry. ${ }^{142}$ While efforts at controlling glomerular diseases from infectious agents like hepatitis $\mathrm{B}$ and $\mathrm{C}$, malaria, and syphilis are yielding positive results among children in Nigeria, ${ }^{34,37,38}$ these children are still at risk of INS. ${ }^{20}$

In light of the foregoing prospective, well-structured, highly powered epidemiological and genetic studies are in dire need in dire Nigeria to describe the pattern of NS in these children, who will be unresponsive to steroids. ${ }^{28-38}$ Hopefully, the H3A-KDRN will be able to answer these research questions in Nigeria and other African countries. ${ }^{58}$

\section{Challenges and opportunities for genetic investigation of childhood nephrotic syndrome in Nigeria}

The challenges facing genetic investigations for NS/SRNS in Nigeria can be captured under two main prongs. The first is inadequate human resources, and the second is inadequate financial resources

\section{Inadequate human resources}

This presupposes that there is accurate information about the diagnosis of childhood NS and/or SRNS that may be needing genetic counseling and genetic testing. There lies the first challenge, as many cases of NS are probably missed because of lack of capacity to diagnose NS/SRNS in the first place.

The current population of Nigeria in 2018 is about 182 million (projected from a 3.5\% growth rate from the 2006 census), ${ }^{143}$ and the country has about 72,000 medical doctors registered with the Medical and Dental Council of Nigeria, among which about half ( 40,000 doctors) are practic- ing in Nigeria. ${ }^{144}$ This gives an approximate unacceptable physician:patient ratio of 1:2,500, as against the World Health Organization's recommendation of $1: 600 .{ }^{144}$ Nigeria has about 400 (adult and pediatric) nephrologists, giving an approximate 0.6 nephrologists per million population. ${ }^{145,146}$ In general and in actual fact, all the potential threats to the nephrology workforce recognized earlier by Sharif et al ${ }^{145}$ are also applicable to Nigeria's setting. These threats include but are not limited to declining interest in postgraduate nephrology training among doctors, the rising costs of medical education and specialist training, an aging workforce, and increasing incidence and prevalence of CKD and ESKD. ${ }^{145}$

This ugly fact of inadequate manpower needed to diagnose and manage renal diseases in Nigeria (including NS/ SRNS) is compounded by a system that loses its trained hands to "brain drain" as doctors migrate to North America and Europe. ${ }^{147-149}$ According to the UK General Medical Council database, the numbers of Nigerian doctors settling in the UK doubled in 2016 compared to 2006, with over 5,000 registered to practice in the UK. ${ }^{147}$ A recent poll in 2018 revealed that the majority of Nigerian doctors (88\%) were seeking to emigrate. ${ }^{147}$ This cut across all cadres of doctors, including junior, midlevel, and senior doctors in all institutions. The same survey revealed the reasons for the continuous brain drain to include high taxes and deduction from salary (98\%), low work satisfaction $(92 \%)$, poor salaries and emoluments (91\%), and the huge knowledge gap that exists in medical practice abroad (47\%). ${ }^{147}$ The few available doctors in Nigeria are also maldistributed, and the referral system is at most inefficient. To illustrate this, a recent survey observed that the northeast region of Nigeria had only one pediatrician for every 700,000 children. ${ }^{150}$

The concern about the quality of care children with NS are receiving in Nigeria was made manifest by a recent publication that revealed that the management of SRNS was significantly different from best-available evidence. ${ }^{151}$ From a study questionnaire administered to heads of pediatric nephrology units, it was found that remarkable variations existed in the dose duration of steroids used for NS across many centers. In addition, $12 \%$ rarely requested a kidney biopsy for SRNS. ${ }^{49}$ Therefore, if challenges remain in the diagnosis and treatment of SRNS, it is plausible that knowledge on the genetics of NS (and the need for genetic investigations in SRNS) will be nonexistent. So far, only one attempt has been made at genetic evaluation among Nigerian children with NS. ${ }^{152}$ In that study, reported by Anochie et al in Port-Harcourt, southern Nigeria, two siblings with familial FSGS were genetically investigated. ${ }^{152}$ The two siblings - a 4-year-old male and a 


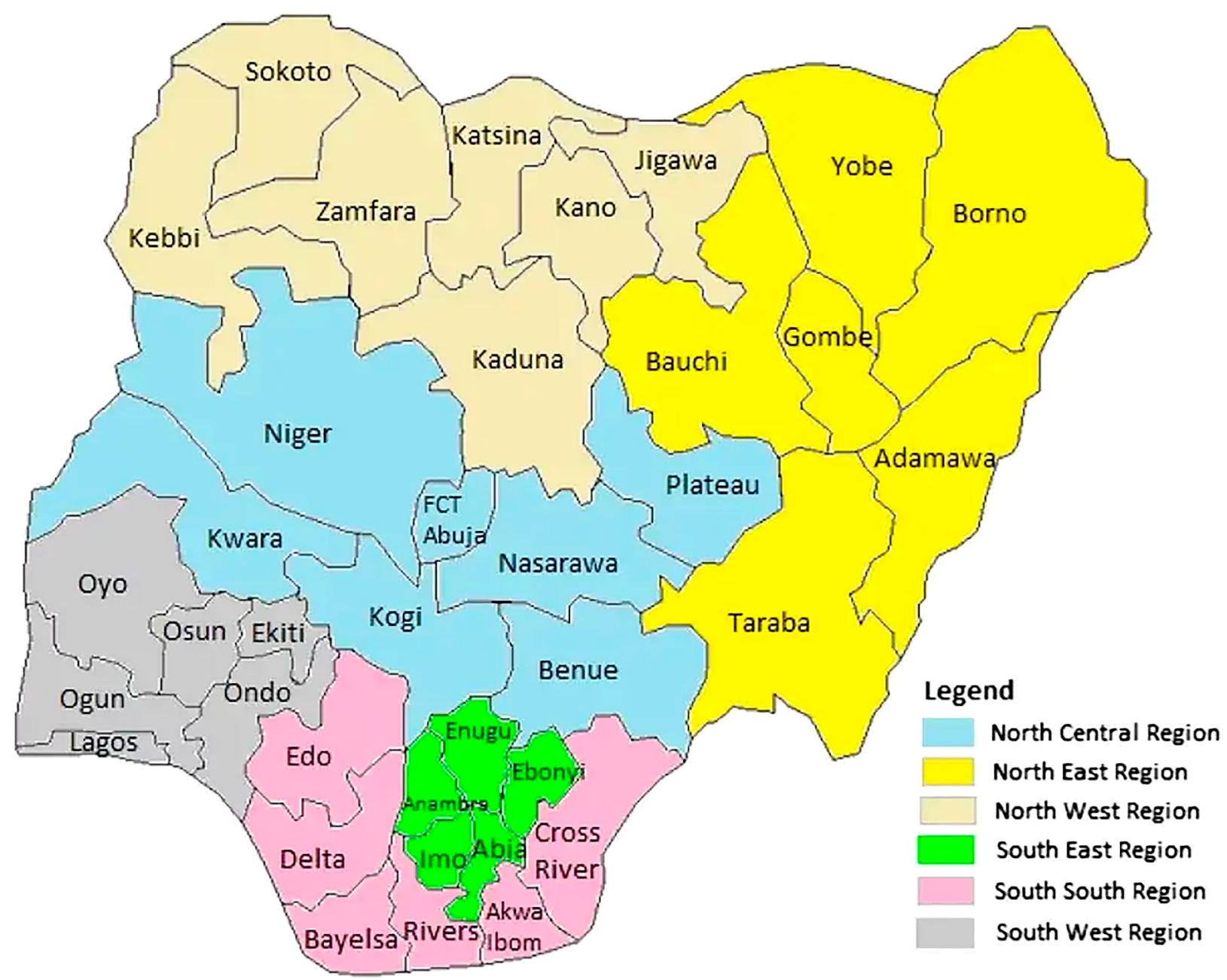

Figure 2 Map of Nigeria's states and zones.

Notes: Reproduced from: https://www.legit.ng/I | 7 | 67 -south-west-states-nigeria.html. ${ }^{140}$

15-year-old female - were from a nonconsanguineous family with renal biopsy-confirmed FSGS who presented with NS. ${ }^{152}$ The mutational analysis performed on the family by sequencing both exons of $N P H S 2, W T 1$, and $A P O L 1$ showed an absence of common mutations in these genes in the two children. The sequencing analysis was also done outside Nigeria. While the sample was small, the authors suggested that there may be different and unidentified gene mutations responsible for FSGS in indigenous African children. ${ }^{152}$

Nigeria lacks the manpower and infrastructure for medical genetics. ${ }^{153}$ Patients with these disorders are largely managed by pediatricians who may be interested in medical genetics, but who have not received formal professional training in genetics. Training opportunities for medical genetics are unavailable within Nigeria. While a few facilities can conduct DNA extraction and even fewer with capacity for sequencing, most genetic studies are conducted outside Nigeria. ${ }^{153}$
Nigeria still lacks a functioning renal registry. ${ }^{154}$ This is partly due to inadequate knowledge and skills for documenting the array of KDs and also to the lack of capacity for renal histopathology and its interpretation. The flawed renal data occasioned by different epidemiological and technical differences in describing renal diseases and pathologies among the available data sources may also explain the lack of a renal registry in Nigeria. Also in Nigeria, like in many developing countries, the focus of most governments is still on infectious diseases, as the lack of data on renal burden fails to convince governments of a paradigm shift toward allocating sufficient funding for prevention and care of renal diseases.

\section{Inadequate financial resources}

Genetic testing for NS is not cheap, and health financing in Nigeria is still largely by patients paying out of pocket. For example, only $3.7 \%$ of gross domestic product was attributed to health expenditure in 2014 , and only $0.9 \%$ of that 
was public-sector funding. ${ }^{155}$ The need to pay out of pocket should also be interpreted against the fact that the minimum wage for Nigerians is $\$ 18,000$ per month (since 2011), up from $\$ 5,500$ per month in $2004 .{ }^{156}$ This $\$ 18,000$ (ie, US\$50 at a conversion rate of $\$ 360$ naira to $\$ 1$ ) translates to $\$ 1.6$ per day, and about 152 million Nigerians live on $<\$ 2$ a day, representing about $80 \%$ of the country's population, according to the African Development Bank in 2018. ${ }^{157}$

Genetic testing is not cheap. It costs $\$ 600-\$ 3,500$ to sequence 26-30 SRNS genes. ${ }^{104}$ This is however expected to reduce, as WES becomes more applicable with the discovery of more genes. ${ }^{14,84}$ Even in developed economies, insurance coverage for genetic testing in NS is not universal. ${ }^{14}$ Not all insurers currently reimburse for genetic testing in NS, as this is not yet considered the standard of care. ${ }^{14}$ Therefore, if developed countries are still finding it difficult to pay for genetic testing, it remains a bigger challenge for Nigeria, whose health system is currently being underfunded.

Although a national health-insurance scheme (NHIS) was launched in $2005,{ }^{158}$ participation is still not mandatory and has very low coverage $(<10 \%)$. Therefore, most health expenses are borne out of pocket. For renal diseases, NHIS covers only six sessions of acute hemodialysis among its enrollees. ${ }^{158}$ Also, Nigeria enacted the National Health Act on October 31, 2014 to set standards for health-care delivery. ${ }^{160}$ This act did not offer much attention to renal care. As such, thus far neither the NHIS nor the act have directly addressed the care of renal diseases, not to mention emerging genetic services or genomic medicine of the 21 st century.

\section{Strengths and opportunities}

In Nigeria, a well-designed, highly powered prospective study is needed to document the genetic predisposition to SRNS involving clinical, electron-microscopy, and immunofluorescence histopathology of SRNS among ethnically black sub-Saharan children. It will allow for baseline data with which comparisons of genetic mutations and varying alleles of those genetic mutations can be made with children of other races. Hopefully, the H3A-KDRN will be able to answer these research questions among Nigerian children with NS/ SRNS. ${ }^{58}$ If a high burden of genetic mutation is demonstrated for Nigerian children with SRNS, it will argue for the inclusion of genetic investigation as the standard of care for these children and for inclusion of its cost as a mandatory part of renal care under the proposed Nigerian Renal Care Policy (NRCP), discussed subsequently.
In Nigeria, the practice of medical genetics may be rudimentary, but it is not in a state of nothingness. ${ }^{153}$ The first clinical and cytogenetic outfit was set up in the early 1970s in Ibadan, Nigeria. ${ }^{153}$ The unit offered clinical and research studies on chromosomal trisomies and other dysmorphic disorders. ${ }^{160-164}$ As such, medical reports of genetic studies were already available in Nigeria in the early 1970s. In those early days, case reports of genetic disorders were published. ${ }^{165,166}$ Adeyokunnu reported the incidence of trisomy 21 as one in 865 live births. ${ }^{161,167}$ Nigeria also has immense experience accrued from the medical genetics of sicklecell disease (SCD). SCD is a common genetic disorder of hemoglobin synthesis that affects $2 \%-3 \%$ of newborns. ${ }^{154}$ Up to $22 \%-25 \%$ of the population has the trait. ${ }^{168-172}$ Most secondary health facilities screen for SCD by hemoglobin electrophoresis at 9 months. ${ }^{173}$ In a few health centers, capacity also exists for HPLC for screening newborns for SCD. ${ }^{153}$ Most knowledge of medical genetics by Nigerian health workers is clinically demonstrable by their ability to explain the genetics of SCD and their ability to provide genetic counseling for couples seeking to get married. Their understanding of genetics can also be seen in their proficiency in explaining the risk of having SCD in offspring of couples with sickle-cell traits. Presently, a prenatal diagnosis of SCD is also available at the Sickle Cell Center in Lagos, Nigeria. ${ }^{153}$ The Sickle Cell Foundation of Nigeria also has the capacity to perform PCR-restriction-fragment length polymorphism analysis for the sickle-cell mutation. ${ }^{153}$

There is also experience in molecular genetics in complex metabolic disorders, such as hypertension, obesity, and diabetes, going back to the 1990 s. ${ }^{174-187}$ Nigerians were also included in population testing for genetic risk factors for malaria and genetic disorders of orofacial clefts, congenital deafness, and congenital heart defects. ${ }^{189-195}$ Nigerian clinicians are also participating in the National Human Genome Research Institute Atlas of Human Malformation Syndromes in Diverse Populations. ${ }^{196,197}$

The H3A-KDRN is jointly funded by the National Institutes of Health and the Wellcome Trust and has invested in several major grants to African investigators for genomic research, capacity building, and improving infrastructure for genome research in Africa. ${ }^{198}$ The H3A-KDRN seeks to determine the association of $A P O L 1$ variants with different rates of CKD in many African settings, including Nigeria, and potential environmental interaction. It will also incorporate causative genetic studies among familial SRNS children aged 15 years and above. ${ }^{199}$ The present proposal seeks to study a 
wider age-range of children (1-18 years) with nonsyndromic familial or sporadic steroid-resistant INS in an ethnically diverse young population in Nigeria.

From the foregoing, it is apparent that Nigeria is not a novice in the field of human genetics and genomic medicine. Lessons learned from earlier experiences ${ }^{153-200}$ can be brought to bear in developing the much-needed infrastructure for genomic medicine (genetic and molecular laboratories for genotyping, sequencing, and bioinformatics) and in building the necessary manpower (genetic counselors, geneticists, cell biologists, and molecular physiologists) required for genetic investigation of SRNS among Nigerian children.

Ultimately, for children with ESKD from SRNS requiring renal transplantation, opportunities already exist for renal transplantation in Nigeria. ${ }^{201}$ In 2000, St Nicholas Hospital, a private hospital in Lagos, performed the first kidney transplant in Nigeria. ${ }^{201}$ Since then, more Nigerian hospitals have transplanted kidneys with Obafemi Awolowo University Teaching Hospital Complex, Ife, Osun state in 2002 being the first among public tertiary health institutions to perform renal transplantation. ${ }^{200,201}$ The hospital complex also has a standard immunology laboratory for proper human leukocyte-antigen typing and tissue cross-matching. ${ }^{201}$

Apart from the challenges of cost and infrastructure, other issues relating to organ donation are being taken care of under the National Health Act of 2014. ${ }^{159}$ The act deals with the illegality of harvesting tissues or organs from a person who cannot give consent or taking tissue from someone aged $<18$ years. ${ }^{159,200}$ The act recognizes that transplantation must be carried out in an authorized hospital with full written authorization of the head of the hospital. ${ }^{159}$ In 2005, the Nigerian Association of Nephrology proposed the NRCP. ${ }^{202}$ The structure of the NRCP included defining and establishing renal care centers, preventive nephrology, funding of renal care, monitoring and evaluation, establishment of a National Kidney Institute, establishment of the renal registry, legislation on an organ-procurement and -transplant program, and developing a robust relationship among states, localgovernment councils, and federal authorities. ${ }^{202}$ Specifically, the NRCP has not as yet made provision for the financing of medical genetics or genomic medicine related to renal diseases in Nigeria. Genomic medicine can be incorporated in the structure of the renal care centers, starting from the tertiary teaching hospitals. The manpower required for genetic analysis can also be developed within the same framework.

An opportunity also exists to expand the scope of the NHIS to cover the exorbitant price of genetic testing within the framework of funding for CKDs, including childhood NS. Another strategy will include advocacy to the Nigerian government to make concerted efforts in stemming the tide of the so-called brain drain by addressing the reasons for the needless emigration of Nigerian doctors, as discussed previously. Nigeria also needs to train more medical doctors to meet the demands of her teeming population. Training and retraining in pediatric nephrology can begin to be the focus of continuing medical education by the Nigerian Medical Council. The capacity to recognize childhood NS and the capacity to know when to refer cases of SRNS to tertiary health centers cannot be overemphasized. Creating and maintaining a registry of children with KD as a composite part of the national renal registry is also much needed.

\section{Conclusion}

Nigeria has more than over 500 indigenous ethnic groups, ${ }^{203}$ thus bolstering the out-of-Africa theory that posits that humans evolved in Africa. ${ }^{204,205}$ Nigeria presents potential genetic variations in genetic causes of NS/SRNS. With prevalence rates of renal diseases among Nigerian children on hospital admission ranging from $1.1 \%$ to $4.5 \%$, NS is also the commonest renal disorder. ${ }^{28,36,206-209}$ With emerging evidence that monogenic FSGS/NS has zero risk of recurrence, ${ }^{141}$ knowing the genetic diagnosis of SRNS is expected to revolutionize the approach to the management of SRNS in childhood. Therefore, the diagnosis of genetic NS will obviate the need for renal biopsy and the unwarranted exposure to immunosuppressive therapy and its attendant complications. Nigeria can leverage its existing experience in genomic medicine to start to include genetic testing for SRNS as part of a standard of care. The NHIS scope can be expanded to include paying for the expensive bill of genetic testing within the structure of the proposed NRCP. The NRCP, while still a "roaring tiger on paper", is bound to improve the care of Nigerians with renal diseases once the policy is put to practical use. As Nigerian nephrologists forge ahead in advocacy for implementation of the NRCP, with expected goodwill from the political establishment, the comprehensive care package contained in the NRCP will soon start to save millions of Nigerians with renal disorders. As the request for genetic testing expands, clinicians will be willing to undergo subspecialty training in human genetics and genomic medicine. As more funding opportunities become available for new research projects, training of manpower and infrastructural development would also become progressively 
available. The advantages of individualized precision medicine that a genetic diagnosis of SRNS portends are too glaring for Nigerian children not also to partake in the 21 st century.

\section{Acknowledgment}

We are grateful to Professor Rasheed Gbadegesin of Duke University Medical Center, Durham, NC, USA for making some articles available for us in the course of this work.

\section{Disclosure}

This work was not carried out in the presence of any personal, professional, or financial relationships that could be construed as a conflict of interest. We report no conflicts of interest.

\section{References}

1. Niaudet P. Steroid-responsive idiopathic nephrotic syndrome in children. In: Avner DE, Harmon EW, Niaudet, editors. Pediatric Nephrology. 5th ed. Philadelphia, PA: Lippincott William \&Wilkin; 2004:543-573.

2. Haraldsson B, Nyström J, Deen WM. Properties of the glomerular barrier and mechanisms of proteinuria. Physiol Rev. 2008;88(2):451-487.

3. Lane JC, Langman CB. Pediatric nephrotic syndrome. Available from: https://emedicine.medscape.com/article/982920-overview. Accessed August 12, 2017.

4. Hodson EM, Wong SC, Willis NS, Craig JC. Interventions for idiopathic steroid-resistant nephrotic syndrome in children. Cochrane Database Syst Rev. 2016;23(9).

5. Rheault MN, Wei CC, Hains DS, Wang W, Kerlin BA, Smoyer WE. Increasing frequency of acute kidney injury amongst children hospitalized with nephrotic syndrome. Pediatr Nephrol. 2014;29(1):139-147.

6. Wong W. Idiopathic nephrotic syndrome in New Zealand children, demographic, clinical features, initial management and outcome after twelve-month follow-up: results of a three-year national surveillance study. J Paediatr Child Health. 2007;43(5):337-341.

7. Eddy AA, Symons JM. Nephrotic syndrome in childhood. The Lancet. 2003;362(9384):629-639.

8. Cochat P, Mourani C, Exantus J, et al. Pediatric nephrology in developing countries. Med Trop. 2009;69:543-547.

9. Rees L, Brogan PA, Bockenhauer D, Webb NJA. Glomerular Diseases in: Paediatric Nephrology. 2nd ed. Oxford: Oxford University Press; 2012:192-216.

10. Downie ML, Gallibois C, Parekh RS, Noone DG. Nephrotic syndrome in infants and children: pathophysiology and management. Paediatr Int Child Health. 2017;37(4):248-258.

11. Nephrotic syndrome in children: prediction of histopathology from clinical and laboratory characteristics at time of diagnosis. A report of the International study of kidney disease in children. Kidney Int. 1978;13(2):159-165.

12. Barnett HL, Edelmanncm, Greifer I. The primary nephrotic syndrome in children. Identification of patients with minimal change nephrotic syndrome from initial response to prednisone. A report of the International study of kidney disease in children. J Pediatr. 1981;98(4):561-564.

13. Gipson DS, Massengill SF, Yao L, et al. Management of childhood onset nephrotic syndrome. Pediatrics. 2009;124(2):747.

14. Gbadegesin RA, Winn MP, Smoyer WE. Genetic testing in nephrotic syndrome-challenges and opportunities. Nat Rev Nephrol. 2013;9(3):179-184.

15. Cochat $P$, Fargue $S$, Mestrallet G, et al. Disease recurrence in paediatric renal transplantation. Pediatr Nephrol. 2009;24(11):2097-2108.
16. van Biljon G. Nephrotic syndrome in children - Studies from South Africa, An update on glomerulopathies - Clinical and treatment aspects. In: Prabhakar S, editor. InTech; 2011;439-454. ISBN: 978-953-307-673-7. Available from: https://www.intechopen.com/ books/an-updateon-glomerulopathies-clinical-and treatment-aspects/ nephrotic-syndrome-in-children-studies-from-southafrica. Accessed 3 January, 2018.

17. Elzouki AY, Amin F, Jaiswal OP. Prevalence and pattern of renal disease in eastern Libya. Arch Dis Child. 1983;58(2):106-109.

18. Elzouki AY, Amin F, Jaiswal OP. Primary nephrotic syndrome in Arab children. Arch Dis Child. 1984;59(3):253-255.

19. Souilmi F, Houssaini T, Alaoui H, et al. Indications and results of renal biopsy in children: a single-center experience from Morocco. Saudi $J$ Kidney Dis Transpl. 2015;26(4):810-815.

20. Olowu WA, Ademola A, Ajite AB, Saad YM. Childhood nephrotic syndrome in tropical Africa: then and now. Paediatr Int Child Health. 2017;37(4):259-268.

21. Gilles HM, Hendrickse RG. Possible aetiological role of Plasmodium malariae in nephrotic syndrome in Nigerian children. Lancet 1960;1(7128):806-807.

22. Gilles HM, Hendrickse RG. Nephrosis in Nigerian children. Role of Plasmodium malariae, and effect of antimalarial treatment. $\mathrm{Br}$ Med J. 1963;2(5348):27-31.

23. Hendrickse RG, Gilles HM. The nephrotic syndrome and other renal diseases in children in western Nigeria. East Afr Med J. 1963;40:186-201.

24. Olowu WA, Adelusola KA, Adefehinti O, Oyetunji TG. Quartan malaria-associated childhood nephrotic syndrome: now a rare clinical entity in malaria endemic Nigeria. Nephrol Dial Transplant. 2010;25(3):794-801.

25. Okoro BA, Okafor HU. Nephrotic syndrome in Nigerian children with homozygous sickle cell disease. East Afr Med J. 1997;74(12):819-821.

26. Ademola AD, Asinobi OO, Oladokun RE, et al. Kidney disease in hospitalised HIV positive children in Ibadan, South West Nigeria. Afr J Med Med Sci. 2012;41(2):221-230.

27. Abdurrahman MB, Aikhionbare HA, Babaoye FA, et al. Clinicopathlogical features of childhood nephrotic syndrome in northern Nigeria. Q J Med. 1990;278:563-576.

28. Eke FU, Eke NN. Renal disorders in children: a Nigerian study. Pediatr Nephrol. 1994;8(3):383-386.

29. Mo I, Abiodun PO. Epidemiology and clinico- pathologic characteristics of childhood nephrotic syndrome in Berlin-City, Nigeria. $J$ Pakistan Med Assoc. 1998;48(8):235-238.

30. Asinobi AO, Gbadegesin RA, Adeyemo AA, et al. The predominance of membranoproliferative glomerulonephritis in childhood nephrotic syndrome in Ibadan, Nigeria. West Afr J Med. 1999;18(3):203-206.

31. Ba O, Okafor HU. Pattern of childhood renal disorders in Enugu. Nig J Paediatrics. 1999;26:14-18.

32. Anochie I, Eke F, Okperea. Childhood nephrotic syndrome: change in pattern and response to steroids. JNat Med Assoc. 2006;98(12):1977-1981.

33. Asinobi AO, Gbadegesin RA, Ogunkunle OO. Increased steroid responsiveness of young children with nephrotic syndrome in Nigeria. Ann Trop Paediatr. 2005;25(3):199-203.

34. Adedoyin OT, Gbelee HOD, Adeniyi A. Childhood nephrotic syndrome in Ilorin. Niger J Paediatr. 2001;28(3):68-72.

35. Olowu WA, Adelusola KA, Adefehinti O. Childhood idiopathic steroid resistant nephrotic syndrome in southwestern Nigeria. Saudi J Kid Dis Transpl. 2010;21(5):979-990.

36. Mo I, Ge O, Ibadin MO, Ofovwe GE. Pattern of renal diseases in children in mid-western zone of Nigeria. Saudi J Kid Dis Transpl. 2003;14:539-544.

37. Ladapo TA, Esezobor CI, Lesi FE. High steroid sensitivity among children with nephrotic syndrome in southwestern Nigeria. Int $J$ Nephrol. 2014;2014:350640.

38. Asinobi AO, Ademola AD, Okolo CA, Yaria JO. Trends in the histopathology of childhood nephrotic syndrome in Ibadan Nigeria: preponderance of idiopathic focal segmental glomerulosclerosis. $B M C$ Nephrol. 2015;16(1):213. 
39. Adeniyi A, Hendrickse RG, Houba V. Selectivity of proteinuria and response to prednisolone or immunosuppressive drugs in children with malarial nephrosis. Lancet. 1970;1(7648):644-648.

40. Hendrickse RG, Adeniyi A, Edington GM, et al. Quartan malarial nephrotic syndrome. Collaborative clinicopathological study in Nigerian children. Lancet. 1972;1(7761):1143-1149.

41. Srivastava T, Simon SD, Alon US. High incidence of focal segmental glomerulosclerosis in nephrotic syndrome of childhood. Pediatr Nephrol. 1999;13(1):13-18.

42. Gulati S, Sharma AP, Sharma RK, Gupta A. Changing trends of histopathology in childhood nephrotic syndrome. Am J Kidney Dis. 1999;34(4):646-650.

43. Bonilla-Felix M, Parra C, Dajani T, et al. Changing patterns in the histopathology of idiopathic nephrotic syndrome in children. Kidney Int. 1999;55(5):1885-1890.

44. Kari JA. Changing trends of histopathology in childhood nephrotic syndrome in Western Saudi Arabia. Saudi Med J. 2002;23(3):317-321.

45. Filler G, Young E, Geier P, Carpenter B, Drukker A, Feber J. Is there really an increase in non-minimal change nephrotic syndrome in children? Am J Kidney Dis. 2003;42(6):1107-1113.

46. Gulati S, Sharma AP, Sharma RK, Gupta A, Gupta RK. Do current recommendations for kidney biopsy in nephrotic syndrome need modifications? Pediatr Nephrol. 2002;17(6):404-408.

47. Rosenberg AZ, Kopp JB. Focal segmental glomerulosclerosis. Clin J Am Soc Nephrol. 2017;12(3):502-517.

48. Kiffel J, Rahimzada Y, Trachtman H. Focal segmental glomerulosclerosis and chronic kidney disease in pediatric patients. Adv Chronic Kidney Dis. 2011;18(5):332-338.

49. Corwin HL, Schwartz MM, Lewis EJ. The importance of sample size in the interpretation of the renal biopsy. Am J Nephrol. 1988;8(2):85-89.

50. Schachter AD. Computational simulation of renal biopsy accuracy in focal segmental glomerulosclerosis. Pediatr Nephrol. 2006;21(7):953-957.

51. Wagrowska-Danilewicz M, Danilewicz M. [Synaptopodin immunoexpression in steroid-responsive and steroid-resistant minimal change disease and focal segmental glomerulosclerosis]. Nefrologia. 2007;27(6):710-715

52. Giannico G, Yang H, Neilson EG, Fogo AB. Dystroglycan in the diagnosis of FSGS. Clin J Am Soc Nephrol. 2009;4(11):1747-1753.

53. Trautmann A, Bodria M, Ozaltin F, et al. Spectrum of steroid-resistant and congenital nephrotic syndrome in children: the PodoNet registry cohort. Clin J Am Soc Nephrol. 2015;10(4):592-600.

54. Ding WY, Koziell A, Mccarthy HJ, et al. Initial steroid sensitivity in children with steroid-resistant nephrotic syndrome predicts posttransplant recurrence. J Am Soc Nephrol. 2014;25(6):1342-1348.

55. Gadegbeku CA, Gipson DS, Holzman LB, et al. Design of the nephrotic syndrome Study network (NEPTUNE) to evaluate primary glomerular nephropathy by a multidisciplinary approach. Kidney Int. 2013;83(4):749-756.

56. Samuel S, Scott S, Morgan C, et al. The Canadian childhood nephrotic syndrome (CHILDNEPH) project: overview of design and methods. Can J Kidney Health Dis. 2014;1:17.

57. Hussain N, Zello JA, Vasilevska-Ristovska J, et al. The rationale and design of insight into nephrotic syndrome: investigating genes, health and therapeutics (insight): a prospective cohort study of childhood nephrotic syndrome. BMC Nephrol. 2013;14:25.

58. NIH Awards by Location and Organization - NIH Research Portfolio. Available from: https://report.nih.gov/award/index.cfm?ot=\&fy=2017 $\&$ state $=86 \& \mathrm{ic}=\mathrm{NIDDK} \& \mathrm{fm}=\&$ orgid $=\& \operatorname{distr}=\& \mathrm{rfa}=\& \mathrm{pid}=$. Accessed 4 March, 2018.

59. Campbell MC, Tishkoff SA. African genetic diversity: implications for human demographic history, modern human origins, and complex disease mapping. Annu Rev Genomics Hum Genet. 2008;9(1):403-433.

60. Benoit G, Machuca E, Heidet L et al. Hereditary kidney diseases: highlighting the importance of classical Mendelian phenotypes. Ann NY Acad Sci. 2010;1214:83-98.
61. D'Agati VD, Fogo AB, Bruijn JA, Jennette JC: Pathologic classification of focal segmental glomerulosclerosis: A working proposal. Am J Kidney Dis. 2004;43:368-382.

62. Marras D, Bruggeman LA, GaoF, TanjiN, Mansukhani MM, Cara A, Ross MD, Gusella GL, Benson G, D’Agati VD, Hahn BH, Klotman ME, Klotman PE: Replication and compartmentalization of HIV-1 in kidney epithelium of patients with HIV-associated nephropathy. Nat Med. 2002;8:522-526.

63. Chandra P, Kopp JB: Viruses and collapsing glomerulopathy: A brief critical review. Clin Kidney J. 2013;6:1-5.

64. Markowitz GS, Appel GB, Fine PL, Fenves AZ, Loon NR, Jagannath S, Kuhn JA, Dratch AD, D'Agati VD: Collapsing focal segmental glomerulosclerosis following treatment with high dose pamidronate. J Am Soc Nephrol. 2001;12:1164-1172.

65. Sakarcan A, Thomas DB, O'Reilly KP, Richards RW: Lithium induced nephrotic syndrome in a young pediatric patient. Pediatr Nephrol. 2002;17:290-292.

66. Letavernier E, Bruneval P, Mandet C, Duong Van Huyen JP, Pe'raldiMN,Helal I, Noe“ 1 LH, Legendre C: High sirolimus levels may induce focal segmental glomerulosclerosis de novo. Clin J Am Soc Nephrol. 2007;2:326-333.

67. Cho ME, Hurley JK, Kopp JB: Sirolimus therapy of focal segmental glomerulosclerosis is associatedwith nephrotoxicity. Am J Kidney Dis. 2007;49:310-317.

68. Mohamed N, Goldstein J, Schiff J, John R: Collapsing glomerulopathy following anthracycline therapy. Am J Kidney Dis. 2013;61: 778-781.

69. Morgan C, Al-Aklabi M, Garcia Guerra G: Chronic kidney disease in congenital heart disease patients: A narrative review of evidence. Can J Kidney Health Dis. 2015;2:27.

70. Aygun B, Mortier NA, Smeltzer MP, Hankins JS, Ware RE: Glomerular hyperfiltration and albuminuria in children with sickle cell anemia. Pediatr Nephrol. 2011;26:1285-1290.

71. Wickman C, Kramer H: Obesity and kidney disease: Potential mechanisms. Semin Nephrol. 2013;33:14-22.

72. Herlitz LC, MarkowitzGS, Farris AB, Schwimmer JA, Stokes MB, Kunis C, Colvin RB, D’Agati VD: Development of focal segmental glomerulosclerosis afteranabolic steroid abuse. J Am Soc Nephrol. 2010;21:163-172.

73. Hanly PJ, Ahmed SB: Sleep apnea and the kidney: Is sleep apnea a risk factor for chronic kidney disease? Chest. 2014;146:1114-1122.

74. Ikezumi Y, Suzuki T, Karasawa T, Yamada T, Hasegawa H, Nishimura H, Uchiyama M: Low birthweight and premature birth are risk factors for podocytopenia and focal segmental glomerulosclerosis. $\mathrm{Am}$ J Nephrol. 2013;38:149-157.

75. Komatsu K, Frohlich ED,Ono H, Ono Y, Numabe A,Willis GW: Glomerular dynamics and morphology of aged spontaneously hypertensive rats. Effects of angiotensin-converting enzyme inhibition. Hypertension. 1995;25:207-213.

76. Savin VJ, Sharma M, Zhou J, Gennochi D, Fields T, Sharma R, McCarthy ET, Srivastava T, Domen J, Tormo A, Gauchat JF: Renal and hematological effects of CLCF-1, a B-Cell stimulating cytokine of the IL-6 family. J Immunol Res. 2015:714964.

77. Lopez-Hellin J, Cantarell C, Jimeno L, Sanchez-Fructuoso A, Puig-Gay N, Guirado L, Vilari no N, Gonzalez-Roncero FM, MazuecosA,LauzuricaR, BurgosD,PlumedJS, Jacobs-CachaC, Jimenez C, Fernandez A, Fernandez-Alvarez P, Torregrosa V, Nieto JL, Meseguer A, Alonso A; GREAT Study Group: A form of apolipoprotein a-I is found specifically in relapses of focal segmental glomerulosclerosis following transplantation. Am J Transplant. 2013;13: 493-500.

78. Delville M, Sigdel TK, Wei C, Li J, Hsieh SC, Fornoni A, Burke GW, Bruneval P, Naesens M, Jackson A, AlachkarN, Canaud G, Legendre C, Anglicheau D, Reiser J, Sarwal MM: A circulating antibody panel for pretransplant prediction of FSGS recurrence after kidney transplantation. Sci Transl Med. 2014;6:256ra136. 
79. Wei C, El Hindi S, Li J, Fornoni A,Goes N, Sageshima J, Maiguel D, Karumanchi SA, Yap HK, Saleem M, Zhang Q, Nikolic B, Chaudhuri A, Daftarian P, Salido E, Torres A, Salifu M, Sarwal MM, Schaefer F, MorathC, Schwenger V, ZeierM,Gupta V, Roth D, Rastaldi MP, Burke G, Ruiz P, Reiser J: Circulating urokinase receptor as a cause of focal segmental glomerulosclerosis. Nat Med. 2011;17:952-960.

80. Lepori N, Zand L, Sethi S, Fernandez-Juarez G, Fervenza FC. Clinical and pathological phenotype of genetic causes of focal segmental glomerulosclerosis in adults. Clin Kidney J. 2018;11(2):179-190.

81. Deegens JKJ, Dijkman HBPM, Borm GF. et al. Podocyte foot process effacement as a diagnostic tool in focal segmental glomerulosclerosis. Kidney Int. 2008;74:1568-1576.

82. Kestila, M. et al. Positionally cloned gene for a novel glomerular protein - nephrin - is mutated in congenital nephrotic syndrome. Mol Cell. 1998;1:575-582.

83. Tae-Sun Ha. Genetics of hereditary nephrotic syndrome: a clinical review. Korean J Pediatr. 2017;60(3):55-63.

84. Rheault MN, Gbadegesin RA. The Genetics of Nephrotic Syndrome. J Ped Gen. 2016;5(1):15-24. DOI http://dx.doi.org/ 10.1055/s-00351557109. ISSN 2146-4596.

85. Kopp JB, Nelson GW, Sampath K, JohnsonRC, GenoveseG,AnP, FriedmanD, BriggsW, Dart R, Korbet S, Mokrzycki MH, Kimmel PL, Limou S, Ahuja TS, Berns JS, Fryc J, Simon EE, Smith MC, Trachtman H, Michel DM, Schelling JR, Vlahov D, Pollak M, Winkler CA: APOL1 genetic variants in focal segmental glomerulosclerosis and HIV-associated nephropathy. JAm Soc Nephrol. 2011;22:2129-2137.

86. Kasembeli AN, DuarteR, RamsayM, Mosiane P, Dickens C, DixPeekT, LimouS, Sezgin E,NelsonGW, FogoAB,GoetschS, Kopp JB, Winkler CA, Naicker S: APOL1 risk variants are strongly associated with HIV-associated nephropathy in black South Africans. J Am Soc Nephrol. 2015;26:2882-2890.

87. Neuhaus TJ, Fay J, Dillon MJ, Trompeter RS, Barratt TM. Alternative treatment to corticosteroids in steroid sensitive idiopathic nephrotic syndrome. Arch Dis Child. 1994;71:522-526.

88. Bennett MR, Pleasant LT, Haffner C, Ma Q, Haffey WD, Ying J, Wagner M, Greis KD, Devarajan P.A Novel Biomarker Panel to Identify Steroid Resistance in Childhood Idiopathic Nephrotic Syndrome. Bio Insights. 2017;12:1-11.

89. Tasic1 V, Gucev Z, Polenakovic M. Steroid resistant nephrotic syndrome-genetic consideration. Sec of Med Sci. 2015;XXXVI 3.

90. Preston R, Stuart HM, Lennon R. Genetic testing is steroid-resistant nephrotic syndrome: why, who, when and how? Pediatric Nephr. 2019;34:195-210.

91. Uwaezuoke SN. The role of novel biomarkers in childhood idiopathic nephrotic syndrome: a narrative review of published evidence. Int $J$ Nephrol Renovascular Dis. 2017:10:123-12

92. Bennett MR, Piyaphanee N, Czech K, Mitsnefes M, Devarajan P. NGAL distinguishes steroid sensitivity in idiopathic nephrotic syndrome. Pediatr Nephrol. 2012;27(5):807-812.

93. Wei C, El Hindi S, Li J, et al. Circulating urokinase receptor as a cause of focal segmental glomerulosclerosis. Nat Med. 2011;17(8):952-960

94. Nourbakhsh N, Mak RH. Steroid-resistant nephrotic syndrome: past and current perspectives. Pediatr Health Med Therap. 2017:8 29-3.

95. Reiser J, Wei C, Tumlin J. Soluble urokinase receptor and focal segmental glomerulosclerosis. Curr Opin Nephrol Hypertens. 2012;21(4):428-432.

96. Matsui I, Hamano T, Mikami S, et al. Retention of fetuin-A in renal tubular lumen protects the kidney from nephrocalcinosis in rats. $\mathrm{Am}$ J Physiol Renal Physiol. 2013;304:F751-F760.

97. Russo LM, Sandoval RM, McKee M, et al. The normal kidney filters nephrotic levels of albumin retrieved by proximal tubule cells: retrieval is disrupted in nephrotic states. Kidney Int. 2007;71:504-513.

98. Sadowski CE, Lovric S, Ashraf S, et al. A single-gene cause in $29.5 \%$ of cases of steroid-resistant nephrotic syndrome. J Am Soc Nephrol. 2015;26:1279-1289.
99. Bierzynska A, Soderquest K, Koziell A. Genes and podocytes - new insights into mechanisms of podocytopathy. Front Endocrinol. 2014;5:226.

100. Ebarasi L, Ashraf S, Bierzynska A, et al. Defects of CRB2 cause steroidresistant nephrotic syndrome. Am J Human Genet. 2015;96:153-161.

101. Miyake N, Tsukaguchi H, Koshimizu E, et al. Biallelic mutations in nuclear pore complex subunit NUP107 cause early-childhoodonset steroid-resistant nephrotic syndrome. Am J Human Genet. 2015;97:555-566.

102. Braun DA, Sadowski CE, Kohl S, et al. Mutations in nuclear pore genes NUP93, NUP205 and XPO5 cause steroid-resistant nephrotic syndrome. Nat Genet. 2016;48:457-465.

103. Gee HY, Zhang F, Ashraf S, et al. KANK deficiency leads to podocytes dysfunction and nephrotic syndrome. J Clin Invest. 2015;125:2375-2384.

104. Lovric S, Ashraf S, Tan W Hildebrandt F. Genetic testing in steroidresistant nephrotic syndrome: when and how? Nephrol Dial Transplant. 2016;31:1802-1813.

105. Gentzon H, Gbadegesin RA. Translating genetic findings in hereditary nephrotic syndrome: the missing loops. Am J Physiol Renal Physiol. 2015 ;309(1):F24-F28. doi:10.1152/ajprenal.00683.2014.

106. Abrahamson DR, Hudson BG, Stroganova L, Borza DB, St. John PL. Cellular origins of type IV collagen networks in developing glomeruli. J Am Soc Nephrol. 2009;20:1471-1479.

107. Akilesh S, Suleiman H, Yu H, Stander MC, Lavin P, Gbadegesin R, Antignac C, Pollak M, Kopp JB, Winn MP, Shaw AS. Arhgap24 inactivates Rac1 in mouse podocytes, and a mutant form is associated with familial focal segmental glomerulosclerosis. J Clin Invest. 2011;121:4127-4137.

108. Caridi G, Trivelli A, Sanna-Cherchi S, Perfumo F, Ghiggeri GM. Familial forms of nephrotic syndrome. Pediatr Nephrol. 2010;25:241-252.

109. Clement LC, Avila-Casado C, Mace C, Soria E, Bakker WW, Kersten S, Chugh SS. Podocyte-secreted angiopoietin-like-4 mediates proteinuria in glucocorticoid-sensitive nephrotic syndrome. Nat Med. 2011;17:117-122.

110. Kitamura A, Tsukaguchi H, Hiramoto R, Shono A, Doi T, Kagami S, Iijima K. A familial childhood-onset relapsing nephrotic syndrome. Kidney Int. 2007;71:946-951.

111. Malone AF, Phelan PJ, Hall G, Cetincelik U, Homstad A, Alonso AS, Jiang R, Lindsey TB, Wu G, Sparks MA, Smith SR, Webb NJ, Kalra PA, Adeyemo AA, Shaw AS, Conlon PJ, Jennette JC, Howell DN, Winn MP, Gbadegesin RA. Rare hereditary COL4A3/COL4A4 variants may be mistaken for familial focal segmental glomerulosclerosis. Kidney Int. 2014;86:1253-1259.

112. Pavenstadt H, Kriz W, Kretzler M. Cell biology of the glomerular podocyte. Physiol Rev. 2003;83:253-307.

113. Buscher AK, Weber S. Educational paper: the podocytopathies. Eur J Pediatr. 2012;171:1151-1160.

114. Kopp, J. B. et al. MYH9 is a major-effect risk gene for focal segmental glomerulosclerosis. Nat Genet. 2008;40:1175-1184.

115. Genovese, G. et al. Association of trypanolytic ApoL1 variants with kidney disease in African Americans. Science. 2010;329:841-845.

116. Hildebrandt F, Heeringa SF. Specific podocin mutations determine age of onset of nephrotic syndrome all the way into adult life. Kidney Int. 2009;75:669-671.

117. Ruf RG, Lichtenberger A, Karle SM et al. Patients with mutations in NPHS2 (podocin) do not respond to standard steroid treatment of nephrotic syndrome. J Am Soc Nephrol. 2004;15:722-732.

118. Hinkes B, Vlangos C, Heeringa $\mathrm{S}$ et al. Specific podocin mutations correlate with age of onset in steroid-resistant nephrotic syndrome. $J$ Am Soc Nephrol. 2008;19:365-371

119. Tory K, Menyhard DK, Woerner S et al. Mutation-dependent recessive inheritance of NPHS2-associated steroid-resistant nephrotic syndrome. Nat Genet. 2014;46:299-304 
120. Tasic V. Genetics of Steroid Resistant Nephrotic syndrome. IPNA teaching course in pediatric nephrology. November 17-19, 2015, Yerevan, Armenia

121. Klaassen I, Ozgoren B, Sadowski CE, Moller K, van Husen M, Lehnhardt A, et al. Response to cyclosporine in steroid-resistant nephrotic syndrome: discontinuation is possible. Pediatr Nephrol. 2015;30(9):1477-83.

122. Cosio FG, Cattran DC. Recent advances in our understanding of recurrent primary glomerulonephritis after kidney transplantation. Kidney Int. 2017;91:304-314

123. Hickson LJ, Gera M, Amer H et al. Kidney transplantation for primary focal segmental glomerulosclerosis: outcomes and response to therapy for recurrence. Transplantation. 2009;87:1232-1239

124. Hofstra JM, Lainez S, van Kuijk WHM et al. New TRPC6 gain -offunction mutation in a non-consanguineous Dutch family with lateonset focal segmental glomerulosclerosis. Nephrol Dial Transplant. 2013;28:1830-1838

125. Jungraithmayr TC, Hofer K, Cochat $P$ et al. Screening for NPHS2 mutations may help predict FSGS recurrence after transplantation. $J$ Am Soc Nephrol. 2011;22:579-585

126. Weber S, Gribouval O, Esquivel EL et al. NPHS2 mutation analysis shows genetic heterogeneity of steroid-resistant nephrotic syndrome and low post-transplant recurrence. Kidney Int. 2004;66:571-579

127. Conlon PJ, Lynn K, Winn MP et al. Spectrum of disease in familial focal and segmental glomerulosclerosis. Kidney Int. 1999;56:1863-1871

128. Chanchlani R, Parekh RS. Ethnic Differences in Childhood nephrotic Syndrome Front Pediatr. 4:39. doi:10.3389/fped.2016.00039.

129. Santín, S. et al. Clinical utility of genetic testing in children and adults with steroid-resistant nephrotic syndrome. Clin J Am Soc Nephrol. 2011;6:1139-1148.

130. Joshi S, Andersen R, Jespersen B, Rittig S. Genetics of steroid-resistant nephrotic syndrome: a review of mutation spectrum and suggested approach for genetic testing. Acta Paediatr. 2013;102:844-56.

131. Bierzynska A, McCarthy HJ, Soderquest K, Sen ES, Colby E, Ding WY, et al. Genomic and clinical profiling of a national nephrotic syndrome cohort advocates a precision medicine approach to disease management. Kidney Int. 2017;91:937-947.

132. Halbritter J, BaumM,HynesAMet al. Fourteenmonogenic genes account for $15 \%$ of nephrolithiasis/nephrocalcinosis. JAm Soc Nephrol. 2015;26:543-551

133. Halbritter J, Diaz K, Chaki M et al. High-throughput mutation analysis in patients with a nephronophthisis-associated ciliopathy applying multiplexed barcoded array-based PCR amplification and next-generation sequencing. J Med Genet. 2012;49:756-767.

134. Teer JK, Mullikin JC. Exome sequencing: the sweet spot before whole genomes. Hum Mol Genet. 2010;19:R145-R151.

135. Conrad DF, et al. Variation in genome-wide mutation rates within and between human families. Nat Genet. 2011;43:712-714.

136. Meyts I, Bosch B, Bolze A, Boisson B, Itan Y, Belkadi A, Pedergnana V, Moens L, Picard C, Cobat A, Bossuyt X, Abel A, Casanova J-L. Exome and genome sequencing for inborn errors of immunity. J Allergy Clin Immunol. 2016;138:957-969.

137. Lee B. Genetic counseling. 20th ed In: Kliegman RM, Stanton BF, St Geme JW, Schor NF, editors. Nelson Textbook of Paediatrics. Philadelphia: Saunders; (2016). p. 582-583.

138. Steps in genetic counselling; brief outline.eachinganatomy.blogspot. com/2013/02/Steps-Genetic-Counseling.html

139. Bhimma R, Coovadia HM, Adhikari M. Nephrotic syndrome in South African children: changing perspectives over 20years. Pediatr Nephrol. 1997; 11:429-434

140. South West States in Nigeria [webpage on the Internet]. Olawale J; 2018. Available from: https://www.legit.ng/1117167-south-west-statesnigeria.html. Accessed April 17, 2019.

141. Pelletier JH, Kumar KR, Engen R, et al. Recurrence of nephrotic syndrome following kidney transplantation is associated with initial native kidney biopsy findings. Pediatr Nephrol. 2018;33(10): 1773-1780.
142. Yirsaw BD. Chronic kidney disease in sub-Saharan Africa: Hypothesis for research demand. Ann Afr Med. 2012;11:119-20.

143. Population. Nigeria's ticking time bomb. Available from: https://www. blueprint.ng/population-nigerias-ticking-time-bomb/. Accessed 6th May 2018.

144. Unease over dearth of physicians in Nigeria's health sector. Available from: https://leadership.ng/2018/09/17/unease-over-dearth-ofphysicians-in-nigerias-health-sector/. Accessed 1st October 2018.

145. Sharif M, Elsayed ME, Stack AG The global nephrology workforce: emerging threats and potential solutions. Clinl Kidney J. 2016;9:11-22.

146. 3 in 10 Nigerian adults have kidney disease, says nephrologists. Available from: https://www.dailytrust.com.ng/3-in-10-nigerian-adultshave-kidney-disease-says-nephrologists.html. Accessed 2nd February 2018.

147. Banke-Thomas A. The emigration of doctors from Nigeria is not today's problem, it is tomorrow's. 15th October, 2018. Available from: https://www.naijiant.com/guestcolumn/the-emigration-of-doctorsfrom-nigeria-is-not-todays-problem-it-is-tomorrows/. Accessed 1st November 2018.

148. Uchenunu-Ibeh O. Nigerian doctors seek work opportunities abroad. 3rd July, 2018. Available from: https://leadership.ng/2018/07/03/88of Nigerian-doctors-seek-work-0opportunities-abroad/. Accessed 3rd August 2018.

149. Nwakanma A. 29th August 2018. The brain drain on Nigeria's health sector spells imminent crisis. Available from: https://thenerveafrica. com/21483/the-brain-drain-on-nigerias-health-sector-spells-imminent-crisis/. Accessed 20th March 2019.

150. Ekure EN, Esezobor CI, Balogun MR, et al. Paediatrician workforce in Nigeria and impact on child health. Nig J Paediatr. 2013;40(2):112-8.

151. Esezobor CI, Asinobi AO, Okafor HU, Akuse R, Gbadegesin R. National survey found that managing childhood nephrotic syndrome in Nigeria varied widely and did not comply with the best evidence. Acta Paediatr. 2018 May 22. Doi:10.1111/apa.14409]

152. Anochie IC, Eke FU, Okpere AN. Familial focal segmental glomerulosclerosis (FSGS) in a Nigerian family and exclusion of mutations in NPHS2,WT1 and APOL1. West Afr J Med. 2012;31:273-6.

153. Adeyemo AA, Amodu OK, Ekure EE, Omotade OO. Medical genetics and genomic medicine in Nigeria. Mol Genet Genomic Med. 2018;6:314-321.

154. Makinde F. 15th February 2017. Stop sending renal patients abroad, minister tells doctors. https://punchng.com/stop-sending-renalpatients-abroad-minister-tells-doctors/. Accessed 13th February 2018.

155. Bhardwaj V. FACT-CHECK: Does Nigeria have the lowest health budget in Africa?. 16th May, 2016. https://www.premiumtimesng. com/features-and-interviews/203494-fact-check-nigeria-lowesthealth-budget-africa.html. Accessed 4th March 2018.

156. Nigerian labour law. https://en.wikipedia.org/wiki/Nigerian_labour_ law]. Accessed 6th April 2018.

157. Amaefule E. 152 million Nigerians live on less than $2 \$ /$ day-AfDB. 6 th February 2018. [https://punchng.com/152-million-nigerians-live-onless-than-2day-afdb. Accessed 6th May 2018.

158. National Health Insurance Scheme. https:/www.nhis.gov.ng/home/. Assessed 25th October 2018.

159. Enabulele O, Enabulele JE. Nigeria's National Health Act: An assessment of health professionals' knowledge and perception. Niger Med J. 2016;57(5):260-265.

160. Adeyokunnu A A. The genetics of omphalocele. Clin Genet. 1981;20(3), 236.

161. Adeyokunnu AA. The incidence of Down's syndrome in Nigeria. JMed Genet. 1982;(19):277-279. doi: https://doi.org/10.1136/jmg.19.4.277

162. Adeyokunnu AA. Spectrum of bone dysplasias in African children: Ibadan Nigerian experience. Prog Clin Biol Res. 1982;104:427-440.

163. Adeyokunnu AA. The incidence of Turner's syndrome in Ibadan, Nigeria. AJMMS. 1982;11(3):105-112.

164. Adeyokunnu AA, Adeniyi A.The Beckwith-Wiedemann syndrome in Nigerian infants (exomphalos, macroglossia and gigantism). East Afr Med J. 1981;58(9):684-690. 
165. Dada TO. Dystrophia myotonica in Nigerian family. East Afr Med J. 1973;50:213-228

166. Familusi J B, Jaiyesimi F, Ojo CO, Attah EDB. Hereditary anhidrotic ectodermal dysplasia: studies in a Nigerian family. Arc Dis Child. 1975;50:642.

167. Adeyokunnu A A. Autosomal trisomy 18 and 13 syndromes in Ibadan, Nigeria. AJMMS. 1983;2:81-89.

168. Akinyanju, OO. A profile of sickle cell disease in Nigeria. Ann $N Y$ Acad Sci. 1989;565:126-136.

169. Fleming AF, Storey J, Molineaux L, Iroko EA, Attai ED. Abnormal haemoglobins in the Sudan savanna of Nigeria.I. Prevalence of haemoglobins and relationships between sickle cell trait, malaria and survival. Ann Trop Med Parasitol. 1979;73:168-172.

170. Jelliffe DB, Humphreys J. The sickle-cell trait in western Nigeria; a survey of 1,881 cases in the Yoruba. Br Med J.1952;23:405-406.

171. Kaine W N, Udeozo IO. Incidence of sickle cell trait and Anaemia in Igbo Preschool Children. Nig J Paediatr. 1981;(8):87-89.

172. Nwogoh B, Adewoyin A S, Iheanacho OE, Bazuaye G N. Prevalence of haemoglobin variants in Benin City, Nigeria. Ann Biomed Sci. 2012;11:60-64

173. Omotade OO, Kayode CM, Falade SL, Ikpeme S, Adeyemo AA, Akinkugbe FM. Routine screening for sickle cell haemoglobinopathy by electrophoresis in an infant welfare clinic. West Afr J Med. 1998;17:91-94.

174. Rotimi C, Morrison L, Cooper R, Oyejide C, Effiong E, Ladipo M et al. Angiotensinogen gene in human hypertension. Lack of an association of the 235T allele among African Americans. Hypertension. 1994;24:591-594.

175. Anderson JL, Bunker CH, Aston CE, Kamboh MI. Relationship of two apolipoprotein B polymorphisms with serum lipoprotein and lipid levels in African blacks. Human Biol. 1997;69:793-807.

176. Kaufman JS, Durazo-Arvizu R A, Rotimi CN, McGee DL, Cooper RS. Obesity and hypertension prevalence in populations of African origin. Epidemiol. 1996;7:398-405.

177. McKenzie CA, Sinsheimer JS, Adeyemo AA, Cox RD, Southam L, Hugill A et al. SNP haplotypes in the angiotensin I-converting enzyme (ACE) gene: Analysis of Nigerian family data using gamete competition models. Ann Hum Genet. 2005;69:227-232.

178. Rotimi CN, Cooper RS, Ataman SL, Osotimehin B, Kadiri S, Muna $\mathrm{W}$ et al. Distribution of anthropometric variables and the prevalence of obesity in populations of west African origin: The International Collaborative Study on Hypertension in Blacks (ICSHIB). Obesity. 1995;3(S2):95-105.

179. Rotimi C, Cooper R, Ogunbiyi O, Morrison L, Ladipo M, Tewksbury D, Ward R. Hypertension, serum angiotensinogen, and molecular variants of the angiotensinogen gene among Nigerians. Circulation. 1997;20(95), 2348-2350.

180. Rotimi C, Puras A, Cooper R, McFarlane-Anderson N, Forrester $\mathrm{T}$, Ogunbiyi $\mathrm{O}$ et al. Polymorphisms of reninangiotensin genes among Nigerians, Jamaicans, and African Americans. Hypertension. 1996;27:558-563.

181. Rotimi CN, Dunston GM, BergK, Akinsete O, Amoah A, Owusu S et al. In search of susceptibility genes for type 2 diabetes in West Africa: The design and results of the first phase of the AADM study. Ann Epidemiol. 2001;11:51-58.

182. Rotimi CN, Chen G, Adeyemo AA, Furbert-Harris P, Parish- Gause $\mathrm{D}$, Zhou J et al. A genome-wide search for type 2 diabetes susceptibility genes in West Africans: The Africa America Diabetes Mellitus (AADM) Study. Diabetes. 2004;53:838-841. https://doi.org/10.2337/ diabetes.53.3.838.

183. Adeyemo AA, Tekola-Ayele F, Doumatey AP, Bentley AR, Chen G, Huang $\mathrm{H}$ et al. Evaluation of genome wide association study associated type 2 diabetes susceptibility loci in sub Saharan Africans. Front Genet. 2015;24(6):335.

184. Chen G, Doumatey AP, Zhou J, Lei L, Bentley AR, Tekola-Ayele F et al. Genome-wide analysis identifies an african-specific variant in SEMA4D associated with body mass index. Obesity. 2017;25(4):794-800.
185. Kang SJ, ChiangCW, Palmer CD, Tayo BO, Lettre G, Butler JL et al. Genome-wide association of anthropometric traits in African- and African-derived populations. Hum Mol Genet. 2010;19: $2725-2738$.

186. Nandakumar P, Lee D, Richard MA, Tekola-Ayele F, Tayo BO, Ware E et al. Rare coding variants associated with blood pressure variation in 15914 individuals of African ancestry. J Hypertens. 2017;35:1381-1389.

187. Reder NP, Tayo BO, Salako B, Ogunniyi A, Adeyemo A, Rotimi C, Cooper RS. Adrenergic alpha-1 pathway is associated with hypertension among Nigerians in a pathwayfocused analysis. PLOS ONE. 2012;7:e37145. https://doi.org/10.1371/journal.pone.0037145

188. Amodu OK, Olaniyan SA, Adeyemo AA, Troye-Blomberg M, Olumese PE, Omotade OO. Association of the Sickle Cell Trait and the ABO Blood Group with clinical severity of malaria in southwest Nigeria. Acta Tropica. 2012;123:72-77.

189. Olaniyan SA, Amodu OK, Bakare AA, Troye-Blomberg M, Omotade OO, Rockett KA, MalariaGEN Consortium. Tumour necrosis factor alpha promoter polymorphism, TNF-238 is associated with severe clinical outcome of falciparum malaria in Ibadan southwest Nigeria. Acta tropica. 2016;161:62-67.

190. Olaniyan SA, Amodu OK, Yindom LM, Conway DJ, Aka P, Bakare AA, Omotade OO. Killer-cell immunoglobulin-like receptors and falciparum malaria in southwest Nigeria. Hum Immunol. 2014;75;816-821.

191. Clarke GM, Rockett K, Kivinen K, Hubbart C, Jeffreys AE, Rowlands $\mathrm{K}$, MalariaGEN Consortium. Characterisation of the opposing effects of G6PD deficiency on cerebral malaria and severe malarial anaemia. eLife. 2017;6:e15085.

192. Butali A, Mossey PA, Adeyemo WL, Eshete MA, Gaines LA, Even D et al. Novel IRF6 mutations in families with Van Der Woude syndrome and popliteal pterygium syndrome from sub-Saharan Africa. Mol Genet Genomic Med. 2014;2(3):254-260.

193. Eshete MA, Liu H Li, Adeyemo WL, Gowans LJJ, Mossey PA et al. Loss-of-function GRHL3 variants detected in African patients with isolated cleft palate. J Dent Res. 2018;97(1):41-48.

194. Gowans LJJ, Oseni G, Mossey PA, Adeyemo WL, Eshete MA, Busch TD et al. Novel GREM1 variations in sub-Saharan African patients with cleft lip and/or cleft palate. Cleft Palate-Cran J.2018;55(5):736-742.

195. Bademci G, Lasisi A, Yariz KO, Montenegro P, Menendez I, Vinueza $\mathrm{R}$ et al. Novel domain-specific POU3F4 mutations are associated with $\mathrm{X}$-linked deafness: Examples from different populations. BMC Med Genet. 2015;16:9. https://doi.org/10.1186/s12881-015-0149-2.

196. Koretzky M, Bonham VL, Berkman BE, Kruszka P, Adeyemo A, Muenke M, Hull SC. Towards a more representative morphology: Clinical and ethical considerations for including diverse populations in diagnostic genetic atlases. Genet Med. 2016;18(11):1069-1074.

197. Muenke M, Adeyemo A, Kruszka P. An electronic atlas of human malformation syndromes in diverse populations. Genet Med. 2016;18(11):1085-1087.

198. H3Africa Consortium. Research capacity. Enabling the genomic revolution in Africa. Science. 2014;344:1346-1348.

199. Osafo C, Raji YR, Burke D, Tayo BO, Tiffin N, Moxey-Mims MM, et al. Human Heredity and Health (H3) in Africa kidney disease research network: a focus on methods in sub-saharan Africa. Clin J Am Soc Nephrol. 2015;10(12):2279-87.

200. Ajayi S O, Raji Y, Salako B L. Ethical and legal issues in renal transplantation in Nigeria. Saudi J Kidney Dis Transpl. 2016;27:125-8.

201. Gbenga-Mustapha O. We can do kidney transplant. 25th June 2013. Available from: http://thenationonlineng.net/we-can-do-kidneytransplant. Accessed 15th January 2018.

202. The Nigerian Association of Nephrology. Proposed National Renal Care Policy. Available from: http://nanephrology.org.ng/index.php/education/proposed-national-renal-care-policy. Accessed 14th December 2017.

203. Nigeria. About the country. Available from: https://en.wikipedia.org/ wiki/Nigeria. Accessed 4th March 2018.

204. Stringer C, and Galway-Witham J. Palaeoanthropology: On the origin of our species. Nature. 2017;546(7657):212-214. 
205. Stringer C. Why we are not all multiregionalists now. Trends Ecol Evol. 2014;29(5):248-251

206. Ezeonwu B, Okike C, Oguonu T, Nwankwo O. Pattern of renal diseases in children admitted into the paediatric ward of Federal Medical Centre Asaba. Afr J Paed Nephrol. 2014;1:8-11.

207. Etuk IS, Anah MU, Ochigbo SO, Eyong M. Pattern of pediatric renal disease in inpatients in Calabar, Nigeria. Trop Doct. 2006;36:256.
208. Ocheke IE, Okolo SN, Bode- Thomas F, Agaba EI. Patterns of childhood renal disorders in Jos, Nigeria: A preliminary report. J Med Trop. 2010;12:52-5

209. Ikpeme EE, Dixon-Umo OT. Paediatric renal diseases in Uyo, Nigeria: a 10-year review. Afr J Paed Nephrol. 2014;1:12-7.
The International Journal of Nephrology and Renovascular Disease is an international, peer-reviewed open access journal focusing on the pathophysiology of the kidney and vascular supply. Epidemiology, screening, diagnosis, and treatment interventions are covered as well as basic science, biochemical and immunological studies. The manuscript management system is completely online and includes a very quick and fair peer-review system, which is all easy to use. Visit http://www. dovepress.com/testimonials.php to read real quotes from published authors.

Submit your manuscript here: https://www.dovepress.com/international-journal-of-nephrology-and-renovascular-disease-journal 